\title{
Efectos de las sentencias anulatorias de re- glamentos, en especial, su retroactividad
}

\author{
Manuel Rebollo Puig \\ Catedrático de Derecho Administrativo \\ Universidad de Córdoba ${ }^{1}$
}

SUMARIO: I. PANORAMA GENERAL DE LOS EFECTOS DE LAS SENTENCIAS ANULATORIAS DE REGLAMENTOS. II. MOMENTO A PARTIR DEL GUAL LAS SENTENCIAS ANULATORIAS DE REGLAMENTOS PRODUCEN EFECTOS. 1. La exigencia de sentencias firmes y publicadas. 2. Consecuencias de las sentencias no firmes anulatorias de reglamentos. 3. Consecuencias de las sentencias firmes en tanto no son publicadas. III. EFECTOS PARA EL FUTURO DE LA DECLARACIÓN DE NULIDAD DE REGLAMENTOS. 1. La regla general. 2. Posibles matizaciones: consecuencias jurídicas para el futuro de los hechos producidos hasta que se anuló el reglamento. IV. EFECTOS SOBRE EL PASADO DE LA DEGLARAGIÓN DE NULIDAD DE REGLAMENTOS. SU EFICACIA RETROACTIVA (EX TUNC). 1. La aniquilación de lo realizado en virtud del reglamento anulado. 2. Las normas de desarrollo (y de modificación) del reglamento anulado que se aprobaron antes de la anulación: nulidad. 3. Los actos administrativos de ejecución del reglamento anulado: validez, nulidad o anulabilidad según los casos. V. EXCEPGIONES A LA RETROACTIVIDAD DE LA ANULACIÓN DE REGLAMENTOS. EL ARTÍCULO 73 LJCA. 1. El art. 73 LJCA y preceptos concordantes. Naturaleza y ámbito de aplicación. 2. Precisiones sobre el significado de los actos sancionadores y de los actos firmes. 3. Los actos no sancionadores firmes de aplicación del reglamento anulado. 4. Los actos sancionadores firmes de aplicación del reglamento anulado. 5. Las sentencias firmes que hubiesen aplicado el reglamento anulado. 6. Efectos "por sí mismas" de las sentencias anulatorias de reglamentos y efectos por vías complementarias ¿Cabe la revisión de oficio?

Grupo de investigación de la Junta de Andalucía SEJ-196. Proyecto DER2015-67695-C2-1-P, MINECO/FEDER, UE). 
RESUMEN: Una combinación de lo poco que dice el legislador y de lo mucho que dice la jurisprudencia está determinando las causas y los efectos de la anulación de los reglamentos. También de los planes de urbanismo. Esa jurisprudencia es sólida y coherente. Pero quizá demasiado apegada a dogmas clásicos sobre la nulidad y excesivamente drástica. Los efectos que prevé para las sentencias anulatorias de los reglamentos es lo que aquí se expone. Sobre todo, sus consecuencias en cuanto a la cesación de efectos del reglamento anulado y a la destrucción de los ya producidos durante su aparente vigencia.

PALABRAS CLAVE: Reglamentos. Nulidad. Sentencias.

ABSTRACT: A combination of what little the legislator says and how much the jurisprudence says is determining the causes and effects of the annulment of the regulations. Also of the urban planning plans. That jurisprudence is solid and coherent. But perhaps too attached to classic dogmas about nullity and excessively drastic. The effects that it foresees for the annulment sentences of the regulations is what is stated here. Above all, its consequences in terms of the cessation of effects of the annulled regulation and the destruction of those already produced during its apparent validity.

KEYWORDS: Regulations. Nullity. Sentences,

\section{PANORAMA GENERAL DE LOS EFEGTOS DE LAS SENTENGIAS ANULATORIAS DE REGLAMENTOS}

Las consecuencias de la anulación de los reglamentos han sido determinadas por la jurisprudencia con mínima base legal. Esa jurisprudencia parte de una premisa que considera inamovible: los reglamentos con vicios invalidantes son nulos de pleno derecho, no anulables. Además, partiendo en todo caso de que los planes de urbanismo son asimilables a los reglamentos ${ }^{2}$, igual nulidad absoluta predica de estos

2 Lo han afirmado desde hace mucho tiempo numerosas sentencias. Por ejemplo, dice la STS de 8 de febrero de 2013 (Ar. 1382; casación 2134/2012): “...sabido es que los planes de urbanismo son disposiciones generales de rango inferior a la ley". CALVO ROJAS, E. "Los planes urbanísticos como disposiciones de carácter general. Problemas que suscita la declaración de nulidad de los instrumentos de planeamiento. Suspensión cautelar de la efectividad de los planes impugnados en vía jurisdiccional", $A d-$ ministración y justicia. Un análisis jurisprudencial. Liber amicorum Tomás-Ramón Fernández, Civitas, 2012, I, pp. 822 a 825, sintetiza esa jurisprudencia y las consecuencias que extrae de tal consideración de los planes como reglamentos.

Algunas veces la doctrina ha puesto en tela de juicio afirmación tan categórica. Vid. por todos BAÑO LEÓN, J. M. Derecho Urbanístico común, Iustel, 2009, pp. 128 a 129; y SANTAMARIA PASTOR, J. A. "Una imprevista disfunción del sistema urbanístico: la mortalidad judicial de los planes", Práctica Urbanística, $\mathrm{n}^{\circ} 141$ (2016), pp. 6 a 8. Y hasta ocasionalmente ello ha tenido reflejo en alguna STS; por ejemplo, la de 25 de junio de 1986 (Ar. 4889), hablando precisamente de planes de urbanismo, dijo: "La distinción 
planes cuando les atribuye algún vicio. Da igual que el vicio del reglamento (o plan) sea de fondo o de forma: siempre proclama esa nulidad de pleno derecho ${ }^{3}$. En teoría, es discutible que la nulidad sea siempre la respuesta que impone nuestro ordenamiento ${ }^{4}$; incluso cabe apuntar que la propia jurisprudencia no es del todo coherente

entre norma y acto tiene bastante de artificial (...). Porque la realidad muestra, más que una contraposición tajante entre acto y norma, una graduación". Luego dice que "esta Sala hace tiempo que se pronunció decididamente en favor de la tesis del carácter normativo de los planes urbanísticos "pero que ello "no implica desconocer la complejidad de su contenido y su función reguladora de una situación concreta y no de un supuesto general abstracto (norma-medida)".

También hay sentencias que al menos reconocen que en los planes de urbanismo hay normas y actos administrativos. Por ejemplo, se lee en la STSJ de Andalucía/Sevilla de 16 de octubre de 2007 (recurso 952/2005; PROV 2008, 58565): "No podemos obviar la naturaleza singular de los planes de urbanismo" donde hay "determinaciones directamente ejecutivas, tal y como si fueran actos administrativos directamente ejecutables, y determinaciones de un claro contenido normativo, susceptibles de desarrollo y ejecución posterior". Son ilustrativas las SSTS de 22 de noviembre de 1994 (casación 208/1992; Ar. 8643), de 27 de mayo de 1999 (casación 2534/1993; Ar. 3647) y de 23 de julio de 1999 (casación 5480/1993; Ar. 6075) que se refieren a la delimitación de las unidades de ejecución que realizaba un plan pero que también podía haberse hecho fuera del plan; ante ello afirman que esa determinación no tiene carácter normativo ni es susceptible de recurso indirecto.

En otro orden de cosas, existe la práctica de formular los recursos contra reglamentos y sobre todo contra planes como si lo que se estuviera impugnando fuese el acto administrativo de aprobación. Aunque en general se trata de una mera formalidad sin trascendencia, esa práctica, a la que a veces se le ha querido dar sustento teórico, no deja de generar dudas y problemas. Por ejemplo, con ello se ha pretendido justificar la posibilidad de recursos administrativos directos contra los planes presentándolos como recursos contra el acto administrativo de aprobación. Todo eso son artificios sin sustancia y deben quedar desterrados hasta afirmar que lo que se puede impugnar y lo que se impugna son los reglamentos o planes (asimilados a reglamentos), no los actos de aprobación que supuestamente ya no tendrían naturaleza normativa.

Un panorama general de las distintas posiciones doctrinales y jurisprudenciales hasta concluir en su naturaleza reglamentaria puede verse en BASSOLS COMA, M. "La asimilación de los planes de urbanismo a normas reglamentarias y problemática jurídica de su anulación judicial”, en G. SORIA MARTÍNEZ y M. BASSOLS COMA (Coords.), Los efectos de la nulidad de los instrumentos de planeamiento urbanístico, Aranzadi, 2017, pp. 36 a 50; y TRAYTER JIMÉNEZ, J. M. El control del planeamiento urbanístico, Civitas, 1996, pp. 42 a 66. Incluso alguna Ley se decanta expresamente por esa opción; así, art. 84.1 de la Ley gallega 2/2016 del Suelo, que califica a los planes como "disposiciones de carácter general".

Entre otras, son particularmente ilustrativas las SSTS de 23 de septiembre de 2003 (rec. 380/1999, Ar. 7789); de 18 de mayo de 2009 (casación 3013/2006; Ar. 4375); de 12 de julio de 2010 (casación 4314/2009; Ar. 7828); de 12 de noviembre de 2010 (Casación 6045/2009; Ar. 8294); de 10 de mayo de 2011 (casación 2072/2007; Ar. 4326); de 18 de noviembre de 2011 (casación 5883/2008; Ar. 2297 de 2012); de 17 de julio de 2012 (casación 5732; Ar. 9124); de 28 de septiembre de 2012 (casación 1009/2011; Ar. 9762); de 13 de diciembre de 2013 (casación 1003/2011; Ar. 8198); de 29 de enero de 2014 (casación 2419/2011; Ar. 1033); de 12 y 25 de mayo de 2015 (casaciones 1920 y 1699/2013; Ar. 2862 y 2712 ); de 27 de noviembre de 2015 (casación 831/2014, Ar. 5922)

4 En realidad, ni siquiera siempre ha sido ésa la postura de la jurisprudencia ni en la doctrina han faltado voces discrepantes. Por el contrario, en su momento diversas SSTS entendieron que, además de existir para los reglamentos irregularidades no invalidantes, incluso cuando tuvieran vicios invalidantes, muchos de ellos (en especial, los de procedimiento) sólo acarreaban su anulabilidad. Una completa exposición de ello ofrece LÓPEZ RAMÓN, F. "La calificación de los vicios de los reglamentos", RAP, n 205 (2018), pp. 15 a 48, quien además se suma a la tesis según la cual también los reglamentos son sólo anulables si tienen 
con esa nulidad ${ }^{5}$. Pero lo cierto es que los tribunales siempre proclaman tal nulidad de pleno derecho de los reglamentos (y planes) viciados. De la premisa de que los reglamentos (o planes) viciados son nulos de pleno derecho, unida a un entendimiento clásico de la nulidad, infieren los tribunales, los efectos de sus sentencias anulatorias de reglamentos (o planes).

Por mucho que teóricamente se diga que los pronunciamientos de nulidad de pleno derecho son meramente declarativos porque en realidad el acto o el reglamento era nulo desde su origen y que la nulidad, por tanto, existía $a b$ initio $^{6}$, esto tiene escasas consecuencias prácticas en el orden administrativo y más bien parece un artificio insustancial ${ }^{7}$ : lo cierto aquí es que, hasta que tal declaración se produce, existe como mínimo una apariencia de acto, reglamento o plan que, unida a su presunción de validez, hace que las llamadas consecuencias de la nulidad sean, en realidad, consecuencias de las declaraciones de nulidad. De este modo, las consecuencias de la nulidad y de la anulabilidad de reglamentos o planes y de actos administrativos se asemejan. Por eso mismo, la LJCA habla indiferentemente de sentencias que anulan actos o reglamentos sin distinguir entre las que propiamente anulan y las que, más exactamente, declaran la nulidad. Y por eso mismo aquí nos referiremos a sentencias anulatorias de reglamentos aunque, con más propiedad, pudiera decirse que son declaratorias de nulidad ${ }^{8}$.

vicios de procedimiento. La misma idea y aplicada a los planes de urbanismo propugna SANTAMARIA PASTOR, J. A. (2016: 8 a 10).

Ello porque los tribunales no admiten que los defectos de procedimiento se puedan alegar en recursos indirectos contra reglamentos como parece más concordante con vicios de nulidad. Vid. DÍAZ GONZÁLEZ, G. M. "Las limitaciones jurisprudenciales del recurso indirecto contra reglamentos", RVAP, n 99-100 (2014), pp. 1161 a 1176; y GÓNZÁLEZ PÉREZ, J. "Una exclusión del recurso contenciosos-administrativo por vía jurisprudencial: el control de vicios de procedimiento de elaboración de disposiciones generales", REDA, nº 9 (1976). Por eso DEL SAZ CORDERO, S. “¿Debemos repensar los poderes del juez ante la constatación de la ilegalidad de una disposición general o acto administrativo? La anulación parcial del Plan General de Madrid de 1997: un inmejorable ejemplo", RVAP, n 99-100, p. 1142, afirma que "los defectos de procedimiento se reconducen, por lo general, a la anulabilidad".

6 En el mismo sentido se dice que la pretensión es declarativa, no constitutiva. Constitutiva sería la que se dirige contra el acto anulable. Pero la que persigue que se declare una nulidad de pleno derecho sería declarativa de una situación que ya existe antes. Vid. por todos HUERGO LORA, A. Las pretensiones de condena en el contencioso-administrativo, Aranzadi, 2000, pp. 43 a 52. Como explica el mismo Huergo, la distinción es relativa y de escasa relevancia práctica para el ámbito administrativo. Frente a ello, ante el acto simplemente anulable, se habrá hecho valer un derecho al cambio jurídico y la sentencia estimatoria será la que produzca realmente la anulación. Vid. PÉREZ ANDRÉS, A. A. Los efectos de las sentencias de la furisdicción Contencioso-Administrativa, Aranzadi, 2000, p. 56.

7 ROSENDE VILLAR, C. La eficacia frente a terceros de las sentencias contencioso-administrativas, Aranzadi, 2002, pp. 68, 91 a 94 y 106.

$8 \quad$ Vid. REBOLlO PUIG, M. "Comentarios a los artículos 72 y 73 LJCA", REDA, no 100 (1998), p. 529 . 
Para exponer los efectos de las sentencias anulatorias de reglamentos procede, conforme a cánones clásicos, distinguir entre los jurídico-materiales y los procesales.

Los primeros se proyectan sobre la realidad jurídica material, no sólo ni directa ni predominantemente sobre la procesal. Además, son propias de cualquier declaración de nulidad de reglamentos (o planes), no específicas de las declaraciones de nulidad pronunciadas por sentencia. Se dan también cuando la declaración de nulidad la realiza una resolución administrativa; típicamente en una revisión de oficio conforme al art. 106.2 $\mathrm{LPAC}^{9}$. Estos efectos jurídico-materiales giran siempre en torno a la misma idea: con la anulación del reglamento (o plan) éste queda expulsado del ordenamiento como si jamás hubiera existido. Pero esta idea se descompone en varias y se completa y matiza con otras. Muy esquemáticamente las siguientes:

a) El reglamento anulado no producirá más efectos en el futuro.

b) Se tiende a aniquilar los efectos que produjo desde su aprobación hasta su anulación.

c) La anulación tiene efectos generales, para todos (erga omnes).

d) Revive el reglamento (o plan) anterior que, en realidad, hay que entender que estuvo siempre vigente.

e) No cabe la conservación de trámites ni la convalidación por subsanación ${ }^{10}$.

\footnotetext{
9 Acaso quepa también la anulación de un reglamento como consecuencia de un recurso administrativo (como era posible antes, cuando se admitían recursos administrativos directos contra reglamentos, o como quizá quepa todavía ahora al resolver un recurso administrativo indirecto contra reglamentos; arg. art. 112.3.2 ${ }^{\circ} \mathrm{LPAC}$ ). En contra, GARCÍA LUENGO, J. "La declaración de nulidad en vía administrativa de disposiciones generales", RAP, $\mathrm{n}^{\circ} 154$ (2001), p. 225; y AGOUÉS MENDIZÁBAL, C. "La modulación de los efectos de la invalidez de los reglamentos", en F. LÓPEZ RAMÓN y F. VILLAR ROJAS (Coords.), El alcance de la invalidez de la actuación administrativa, AEPDA/INAP, 2017, p. 397.

10 Entre las muchas sentencias que proclaman estos efectos, compendia varios de ellos, aunque refiriéndolos concretamente a planes de urbanismo, la STS de 2 de marzo de 2015 (casación 3160/2013, Ar. 1782) al decir que, conforme a "reiterada jurisprudencia... (1) los planes de urbanismo son disposiciones de carácter general, esto es, normas de rango reglamentario, de modo que no puede resultar de aplicación el art. 67 Ley 30/1992, (2) los vicios de que adolecen las disposiciones de carácter general son vicios de nulidad plena, respecto de los cuales carece de fundamento la convalidación. (3) los vicios de invalidez en que pueden incurrir las disposiciones de carácter general son únicamente supuestos de nulidad plena, y (4) la nulidad de pleno derecho no admite convalidación pues no se trata de un simple supuesto de anulación sino de nulidad con efectos ex tunc". Y lo hace en estos términos la STS de 25 de mayo de 2015 (casación 1699/2013; Ar. 2712): "En síntesis, venimos a afirmar que, por tratarse los planes urbanísticos de disposiciones de carácter general, las infracciones del ordenamiento jurídico que pudieran producirse (...) dan lugar a la nulidad de pleno derecho (...) De lo que sigue, entre otras consecuencias, la eficacia ex tunc de la propia declaración de nulidad de un plan y la imposibilidad de proceder a su convalidación mediante la
} 
Los efectos procesales son sólo propios de las anulaciones de reglamentos acordadas por sentencia y se proyectan esencialmente sobre otros procesos: son declarativos y ejecutivos.

Los declarativos se asientan en torno al concepto de cosa juzgada material con sus dos funciones, la excluyente (o negativa) y la prejudicial (o positiva). Las sentencias desestimatorias de los recursos directos contra reglamentos no tiene fuerza de cosa juzgada (art. 26.2 LJCA). Pero las estimatorias, esto es, las que anulan el reglamento, que son las que nos interesan, sí la tienen. La tienen todas ellas: tanto las anulatorias producidas en un recurso directo contra el reglamento como las recaídas al resolver una cuestión de ilegalidad o las que eventualmente se produzcan al resolver un recurso indirecto si el tribunal también es competente para resolver el directo. No obstante, la cosa juzgada tiene muchos límites, objetivos y subjetivos, y cuando no puede aplicarse los tribunales acuden con frecuencia a la idea de pérdida sobrevenida del objeto del proceso para no volver a resolver sobre la nulidad en un nuevo recurso contra el mismo reglamento: si el reglamento ahora impugnado ya fue declarado nulo ni el nuevo proceso tiene objeto (ya desapareció para el Derecho) ni hay interés en otra declaración de nulidad.

Los efectos ejecutivos entrañan la obligatoriedad de cumplimiento y, en su defecto, la posibilidad de ejecución forzosa judicial. Conforme a las concepciones más ortodoxas y lógicas, esos efectos ejecutivos son sólo propios de las sentencias de condena. Predicarlos de las sentencias meramente declarativas (como son las anulatorias de reglamentos que aquí nos incumben) o de las sólo constitutivas parece un absurdo. Pero la profundización en el derecho a la tutela judicial efectiva en su vertiente de derecho a la ejecución de sentencias ha propiciado, por extraño que resulte, que también las sentencias contencioso-administrativas puramente declarativas y constitutivas puedan ser objeto de procesos de ejecución y, aun más chocante, de incidentes de imposibilidad de ejecución. De hecho, no son pocos los pronunciamientos judiciales recaídos en incidentes de ejecución de sentencias anulatorias de reglamentos o, sobre todo, de planes de urbanismo. El art. 103.5 LJCA es el sustento más habitual.

Junto a ese marco general de efectos materiales y procesales de las sentencias, se habla también de efectos indirectos o reflejos ${ }^{11}$. Son en realidad consecuencia de los efectos hasta ahora expuestos y de su suma a diversos preceptos materiales muy heterogéneos en cuyos presupuestos de hecho puede subsumirse tal declaración de

subsanación del defecto que hubiera podido producirse". También resume bien todo esto la STS de 2 de marzo de 2016 (casación 1626/2015; Ar. 940).

11 Vid. PÉREZ ANDRÉS, A. A. (2000: 54-55) y ROSENDE VILLAR, C. (2002: 99). 
nulidad. Puede tratarse de consecuencias penales ${ }^{12}$. O de consecuencias civiles ${ }^{13}$. También, por supuesto, diversas consecuencias administrativas, incluidas las tributarias. Entre ellas, eventualmente, puede generarse la responsabilidad patrimonial de la Administración ${ }^{14}$.

12 Así, v. gr., en tanto que hay normas penales en blanco que deben integrarse con el plan o reglamento, la nulidad de éste podrá comportar que no haya tipicidad ni acaso siquiera antijuridicidad. En realidad, esa nulidad del plan también la puede invocar el inculpado (excepción de nulidad) y la puede apreciar el Tribunal penal a sus efectos sin necesidad de que antes se haya declarado la nulidad del plan. Pero si ésta se ha declarado ya por sentencia contencioso-administrativa el Tribunal penal tendrá que partir de ella como premisa indiscutible. Y, a la inversa, puede que el hecho de la ilegalidad y nulidad del plan sea ocasionalmente requisito para entender cometido el delito (por ejemplo, el del art. $506 \mathrm{CP}$ ) y en tal hipótesis la sentencia contencioso-administrativa anulatoria del plan será igualmente premisa segura e incuestionable. Todo esto son consecuencias establecidas por preceptos penales (los que tipifican cada delito, los que consagran eximentes, etc.) no de los que se ocupan de los efectos de las sentencias contencioso-administrativas. Pero para aplicar aquéllos hay que tener en cuenta estos.

${ }_{13}$ Esto se presenta con especial intensidad ante la anulación de planes de urbanismo. Vid. SORIA MARTÍNEZ, G. y GARBAYO BLANCH, J. "Consecuencias de la nulidad del plan sobre los contratos civiles de transmisión”, en G. SORIA MARTÍNEZ y M. BASSOLS COMA (Coords.), Los efectos de la nulidad de los instrumentos de planeamiento urbanístico, Aranzadi, 2017, pp. 263 y ss. Y serán consecuencias que, en su caso, habrá que declarar en procesos civiles en los que la sentencia contencioso-administrativa anulatoria del reglamento jugará como premisa.

14 Aunque el mero hecho de la anulación no comporta per se derecho a indemnización (art. 32.1.2 LRJSP), la responsabilidad patrimonial de la Administración se puede basar en las reglas generales que se contienen en la LRJSP. En el caso de anulación de planes de urbanismo, tal vez pueda encontrar su fundamento o su complemento en las específicas de la legislación del suelo; ahora en el art. 48 TRLS/2015 y más concretamente el de su apartado a) si es que se asimilase la declaración de nulidad de un plan al "cambio de la ordenación territorial y urbanística (...) antes de transcurrir los plazos previstos para su desarrollo" que es lo que en él se prevé expresamente. Esa asimilación la afirma rotundamente IGLESIAS GONZÁLEZ, F. "Responsabilidad patrimonial por nulidad del planeamiento", en G. SORIA MARTÍNEZ y M. BASSOLS COMA (Coords.), Los efectos de la nulidad de los instrumentos de planeamiento urbanístico, Aranzadi, 2017, pp. 351 y 362, con invocación de la STS de 17 de octubre de 1988 (Ar. 7760). En realidad, esa interesante STS no llega a basar la indemnización en casos de nulidad del plan en las normas previstas para la indemnización en caso de modificación anticipada. Lejos de ello, dice que se trata de una responsabilidad por "funcionamiento anormal de los servicios públicos", lo que no se da en la modificación anticipada. En cualquier caso, sólo admite la indemnización para los "propietarios que habiendo adquirido los terrenos al precio resultante de las posibilidades urbanísticas del Plan (...) aparentemente en vigor se ven después afectados por la pérdida de valor que representa la imposibilidad de urbanizar determinada por la anulación", no para los propietarios que ya lo eran antes de la aprobación del plan. Sea como fuere, lo que no tiene sentido es pensar que, tras la anulación de un plan, el que se apruebe en el futuro haya de contener previsiones sobre esas indemnizaciones en su estudio económico financiero o en su informe de sostenibilidad económica. Lo que a lo sumo ha llegado a exigir el TS (véase su sentencia de 18 de diciembre de 2009 (casación 4424/2005; Ar. 2918 de 2010) es que los planes contengan previsión de indemnizaciones cuando su "finalidad primera es precisamente limitar el aprovechamiento de planes con obras de urbanización ejecutadas o en ejecución, e incluso limitar el aprovechamiento adquirido en licencias ya otorgadas". Pero ése no es el caso que se produce con la anulación de un plan y la aprobación de otro posterior en tanto que de aquél no derivarán situaciones patrimoniales consolidadas ni éste tiene por finalidad restringir aprovechamientos patrimonializados legalmente. La responsabilidad surgirá, si acaso, del plan anulado, no del nuevo. 
Un peculiar efecto de las sentencias anulatorias de reglamentos (y especialmente de las anulatorias de planes) es que comportan un límite adicional para el ejercicio posterior de la potestad reglamentaria (y de la potestad de planeamiento). Un límite en cuya virtud el futuro ejercicio de la potestad reglamentaria y de planeamiento se verá especialmente constreñido hasta el extremo de que su vulneración será considerado incumplimiento de la sentencia y su nulidad podrá ser declarada en trámite de ejecución.

De todas estas consecuencias de las sentencias anulatorias de reglamentos aquí nos vamos a ocupar sólo de la cesación de efectos jurídicos para el futuro y, sobre todo, de la destrucción de los efectos ya producidos antes de la anulación judicial, que es lo más problemático.

Pero con carácter previo es necesario abordar desde qué momento producen efectos las sentencias anulatorias de reglamentos.

\section{II: MOMENTO A PARTIR DEL GUAL LAS SENTENGIAS ANULA- TORIAS DE REGLAMENTOS PRODUGEN EFECTOS}

\section{La exigencia de sentencias firmes y publicadas}

Como advertimos antes, los efectos de la nulidad de un reglamento no son realmente los efectos de que tenga vicios de nulidad sino los efectos de la declaración de nulidad; que mientras no haya tal declaración, por mucho que el reglamento tenga vicios, la Administración y los administrados tienen que comportarse como si fuese válido. Es importante saber desde qué momento hay que partir ya, no de la presunción de validez del reglamento, sino de todo lo contrario, de su nulidad. Este será el momento a partir de cual se producirán los efectos descritos.

No cabe duda de que los efectos procesales sólo se producen cuando haya sentencia anulatoria firme. Eso es indiscutible tanto para los efectos derivados de la cosa juzgada como para los ejecutivos. Los preceptos de la LJCA no dejan lugar a dudas y es así conforme a principios generales de todo el Derecho Procesal. A lo sumo cabe introducir el matiz de la posibilidad de ejecución provisional de sentencias no firmes que, en realidad, no afecta a lo dicho porque esa ejecución provisional es, en el fondo, una especie de medida cautelar aunque con un régimen singular.

Pero, primero, el art. 72.2 LJCA introduce respecto a la eficacia general (erga omnes) de la anulación de disposiciones generales (reglamentos o planes) un requisito adicional: sólo la tendrá "desde el día en que sea publicado su fallo y preceptos anulados en el mismo periódico oficial en que lo hubiera sido la disposición anulada". Ante 
ello hay que preguntarse qué sucede cuando hay sentencia anulatoria firme no publicada. Y, segundo, ¿qué sucede cuando hay una sentencia anulatoria no firme desde que se dicta hasta que gana firmeza? ¿qué sucede durante el tiempo -que pueden ser años- hasta que se resuelve la apelación y/o casación de que haya sido objeto? Ya sabemos que no tiene propiamente efectos de cosa juzgada material y que, desde luego, no es ejecutiva (sin perjuicio de la eventual ejecución provisional). Pero, ¿tampoco tiene efectos jurídico-materiales? ¿tampoco afecta a las partes? El reglamento o plan anulado por sentencia no firme ¿puede seguir siendo aplicado por Administración y tribunales como si nada hubiera pasado todavía?

Responderemos a estos dos géneros de cuestiones en orden inverso a cómo las hemos planteados. Primero abordaremos la situación que se produce ante sentencias anulatorias mientras no son firmes. Después la situación ante las sentencias anulatorias firmes no publicadas.

\section{Consecuencias de las sentencias no firmes anulatorias de reglamentos}

La pregunta es si todos (particulares, Administración y tribunales), en tanto que la sentencia anulatoria no sea firme, deben comportarse como si el reglamento fuese válido, como si conservara su presunción de validez, o si, por el contrario, deben actuar como si fuese nulo.

Una primera posibilidad es afirmar que mientras sólo haya sentencia anulatoria no firme, hay que seguir aplicando el reglamento como si nada hubiera pasado. Alguna vez ha sido acogida por los tribunales ${ }^{15}$.

En el extremo opuesto, cabe sostener que la sentencia anulatoria, aunque todavía no firme condiciona absolutamente lo que debe hacer la Administración que, por tanto, sin esperar a la firmeza ni a la publicación, debe dejar de aplicar el reglamento y, en su caso, empezar a aplicar la norma rediviva. También vincula a los tribunales al enjuiciar las actuaciones administrativas producidas en ese periodo y, a la larga,

15 Así, STS de 23 de noviembre de 2000, recurso 5687/1996, Ar. 431 de 2001, que cita otras. En ese sentido DE COMINGES CÁCERES, F. "Los efectos de la anulación judicial de un plan general. La necesaria modulación de la equiparación de planes y disposiciones reglamentarias. Propuestas de mejora del sistema", Revista de Derecho Urbanístico y Medio Ambiente, no 314 (2017), pp. 61 a 63, aunque propone como solución acordar la suspensión de licencias o instar la ejecución provisional de la sentencia. HUERGO LORA, A. «Los efectos en otros procesos de las sentencias no firmes que declaran la nulidad de un reglamento», en E. GARCÍA DE ENTERRÍA y R. ALONSO GARCÍA (Coords.), Administración y justicia. Un análisis jurisprudencial. Liber amicorum Tomás-Ramón Fernández, Civitas, 2012, I, pp. 1473-1476, expone y critica con acierto esta tesis. 
consecuente e indirectamente, a los sujetos privados. También esta tesis ha encontrado respaldo en varias sentencias ${ }^{16}$.

La respuesta correcta ${ }^{17}$ y la mayoritariamente acogida por el TS es intermedia. Para exponerla distingamos la posición de los tribunales en otros procesos y la posición de la Administración.

\section{A) Para los tribunales}

Para los tribunales, la solución se puede formular así: para resolver otros procesos, los tribunales, aunque no están irresistiblemente obligados por la sentencia anulatoria anterior no firme, deben tomarla en consideración y normalmente actuar en coherencia con ella. Razonémosla.

En todo proceso en que un tribunal haya de aplicar un reglamento o plan puede cuestionarse su legalidad; naturalmente si se trata de un proceso cuyo objeto sea precisamente la nulidad de ese reglamento o plan debe hacerlo puesto que el fallo dependerá exclusivamente de ello; pero también puede hacerlo en cualquier otro (por ejemplo, proceso contra una licencia de aplicación de un plan). Es resultado del

\footnotetext{
16 Sobre todo se apoyan en la idea de que la firmeza y la publicación de la sentencia anulatoria sólo se exige en el art. 72.2 LJCA para que tenga efectos generales, pero no para que tenga efectos entre las partes: para éstas, entre las que está la Administración autora del reglamento, su vinculación a la anulación no necesita de la firmeza ni de la publicación. HUERGO LORA, A. (2012: 1476-1477); y MUÑOZ MACHADO, S. y CARRO MARINA, M. "La eficacia de las sentencias no firmes (impugnación de una corriente jurisprudencial: desde la sentencia de 17 de septiembre de 2008 a la de 10 de octubre de 2011)", en GARCÍA DE ENTERRÍA, E., y ALONSO GARCÍA, R. (Coords.), Administración y justicia. Un análisis jurisprudencial. Liber amicorum Tomás-Ramón Fernández, Civitas, 2012, I, pp. 1807 a 1827, dan cuenta de esta jurisprudencia que sigue coleando. Muestra de ello posterior a esos dos estudio es la STS de 12 de mayo de 2015 (Casación 1920/2013; Ar. 2862): "La falta de firmeza de la sentencia (que anuló el plan) por sí sola (...) no impide al Tribunal sentenciador enjuiciar las disposiciones o actos administrativos que traen causa o derivan de dicho plan declarado nulo (...) sobre la base necesaria de dicha nulidad, a la que no se puede atribuir una virtualidad condicionada a la firmeza". Quizá también STS, Sección 2a , de 4 abril 2012 (Ar. 5177 . Casación 5301/2008): ante una STSJ que anuló un reglamento pero que estaba pendiente de casación, dice: "mientras nuestra sentencia (la del TS) no se produzca, ha de considerarse plenamente ajustado a derecho lo declarado por el tribunal de instancia". En la misma dirección la sentencia recurrida dijo: "con independencia de que dicha sentencia (...) sea o no firme en estos momentos y del criterio último que el TS pueda acoger al respecto, la Sala ha de optar por su inaplicación en aras del principio que emana del art. 91.1 LJCA $(<<$ La preparación del recurso de casación no impedirá la ejecución provisional de la sentencia recurrida $>>$ ) y del propio postulado del art. 6 LOPJ". Critica esta opción HUERGO LORA, A. (2012: 1477). Y lo hacen también demoledoramente MUÑOZ MACHADO, S., y CARRO MARINA, M. en el estudio recién citado. Los argumentos de estos trabajos son, entendemos, irrefutables pues demuestran cumplidamente que esta tesis vulnera los efectos suspensivos de los recursos (incluido el de casación), es contraria a la regulación de la ejecución provisional de las sentencias, no es adecuada a la tutela judicial efectiva y, para colmo, tampoco encuentra apoyo en la literalidad del art. 72.2 LJCA a la que, más bien, tergiversa.

17 En línea con lo explicado por HUERGO LORA, A. (2012: 1478 y ss.) y por MUÑOZ MACHADO, S. y CARRO MARINA, M. (2012: 1822 a 1824).
} 
art. 6 LOPJ y es consustancial a cualquier recurso indirecto contra reglamentos ${ }^{18}$. En ese enjuiciamiento del reglamento o plan no está vinculado por la fuerza de la cosa juzgada de la sentencia anulatoria anterior porque partimos de que no es firme. Pero, aun así, en tal juicio sobre la legalidad del reglamento, puede y hasta debe tener en cuenta la sentencia anulatoria que ya se ha dictado, máxime si la dictó el mismo tribunal, por mor de la coherencia y del principio de unidad de doctrina. Insistamos: no es que el tribunal en otro proceso esté absolutamente vinculado por esa sentencia anterior; pero debe tomarla en consideración y, salvo motivación en contrario, acoger la conclusión de aquélla. Puede que simplemente cite la sentencia no firme que anuló el reglamento y que eso le sirva sin más para fundamentar su juicio de nulidad de ese reglamento; puede que cite y reproduzca los argumentos de aquella sentencia como justificación de su juicio de nulidad del reglamento; o puede que, sin ni siquiera citar nada de aquella sentencia, con sus mismos argumentos o con otros, concluya que el reglamento es nulo. Nada de eso importa; estas variedades son lo de menos. Lo importante es que, sin invocar la cosa juzgada material ni los efectos jurídico-materiales de la sentencia anterior, concluya que el reglamento es nulo y que, sobre ese presupuesto, se pronuncie sobre la validez o invalidez del acto que lo aplicó (o del reglamento que lo desarrolló), lo que normalmente le llevará a su anulación. Pero no siempre tiene que actuar así. Puede actuar de otra forma sin incurrir por ello en una ilegalidad. Por una parte, puede entender, en contra de lo razonado por la sentencia no firme que anuló el reglamento, que éste es válido. Sobre todo eso será perfectamente posible y lícito si se trata de un órgano distinto del que dictó la sentencia no firme anulatoria del reglamento. Será mucho más extraño si se trata del mismo órgano, aunque tampoco eso es imposible ni necesariamente ilegal si lo motiva suficientemente.

Esta es la solución que hoy domina en el TS. De entre las sentencias en esta dirección, la de 22 de noviembre de 2012 (casación 1562/2010; Ar. 10911) resulta representativa y suficientemente clara: la proyección de una sentencia anulatoria "cuando no era todavía firme, a otro litigio sobre el mismo objeto o sobre otros derivados o encadenados" es correcta porque "la base de la decisión no se encuentra en una prematura extensión erga omnes de los efectos de la sentencias que anulan disposiciones generales, ni en una aplicación indebida del efecto positivo de la cosa juzgada, que exige, por definición, que la sentencia de que se trate sea firme". La justificación es otra:

"Sucede que, aun careciendo de firmeza la sentencia que anula la disposición, como es un instrumento de ordenación, nada impide que la propia Sala de instancia anule también, en coherencia con aquélla, los planes

18 Vid. AGOUÉS MENDIZÁBAL, C. (2017: 373). 
conectados y derivados, en razón de que sobre el nuevo acuerdo se proyectan y trascienden los vicios de nulidad apreciados en la primera sentencia. A esta conclusión conducen la necesidad de coherencia de las resoluciones judiciales que abordan cuestiones idénticas o sustancialmente iguales, y, en definitiva, el principio de seguridad jurídica ${ }^{19}$ ".

\section{B) Para la Administración}

Más difícil es la situación en la que se encuentra la Administración que aprobó el reglamento o plan anulado por sentencia no firme. Juegan diversos factores en dirección contraria ${ }^{20}$. De un lado, la presunción de validez que ha de otorgar a los

19 Exactamente en los mismos términos, existe otra STS de la misma fecha que resolvió la casación 1753/2010 (Ar. 333 de 2013). Estas sentencias citan en su apoyo la STS de 24 de septiembre de 2008 (casación 4180/2004). Véanse también las SSTS de 20 de noviembre de 2009 (casación 4917/2005), 17 de septiembre de 2009 (casación 4924/2005), 29 de abril de 2009 (casación 157/2005; Ar. 5143), 24 de septiembre de 2008 (casación 4180/2004), 12 de junio de 2007 (casación 7487/2003) y 16 de diciembre del 2010 (casación 4451/2006), entre otras. De entre éstas vale la pena recordar la STS de 17 de septiembre de 2009 (casación 4924/2005; Ar. 822 de 2010): en una STSJ de la Rioja de 17 de octubre de 2003 se anuló la modificación puntual de un PGOU por incurrir en "un importante déficit de espacios libres"; por otra parte, se impugnó separadamente (no en ejecución de la sentencia anterior) un Proyecto de Compensación y fue anulado por STSJ de la Rioja de 5 de mayo de 2004 "por el único motivo de que se había anulado previamente (...) la modificación puntual del PGOU que estableció la ordenación detallada del ámbito en cuestión"; esta STSJ de la Rioja de 5 de mayo de 2004 es la que se recurrió en casación porque cuando se dictó la anterior de 17 de octubre de 2003 no era firme (estaba recurrida ante el TS). Para la STS de 17 de septiembre de 2009 no es relevante que no fuese firme: “... aún careciendo entonces de firmeza, constituía causa suficiente para que la misma Sala que la dictó anulase en congruencia con aquélla los posteriores actos de aplicación del plan urbanístico que había declarado nulo, en los que se reprodujo el mismo vicio de nulidad, y en los que concurren las mismas partes afectadas (artículo 72.2 "ab initio" de la Ley Jurisdiccional). Así lo exige un mínimo criterio de coherencia y de seguridad jurídica (...) Si bien en casos como el presente, el órgano de instancia debe entrar a estudiar y resolver todos los motivos de impugnación esgrimidos en la demanda, en prevención de que el órgano superior revoque la anterior sentencia que se toma como base de la decisión". Mas reciente y reseñable es la STS de 30 de enero de 2014 (casación 3045/2011; Ar. 802): no impone al tribunal que parta irresistiblemente de la nulidad del plan declarada por sentencia no firme ("la anulación de un reglamento por una resolución judicial carente de firmeza no vincula por sí sola") pero sí que dice que ello "no quiere decir que el propio órgano jurisdiccional que ha estimado la procedencia de anular un reglamento pueda sin más simplemente con base en ello apartarse de su propia doctrina" sino que "resulta exigible al enjuiciamiento jurisdiccional un grado de coherencia suficiente, de modo que no puede desvincularse de sus resoluciones precedentes y de las consecuencias a que éstas desembocan sin aportar alguna razón más allá de la falta de firmeza de aquéllas" porque, caso de actuar así, "sin ofrecer una razón, (...) su actuación resultaría sencillamente inconsistente". En suma, acepta que una sentencia se aparte de otra anterior no firme anulatoria de un plan pero sólo si lo hace motivadamente. Y en igual dirección es clara la STS de 13 de junio de 2014 (casación 160/2012; Ar. 3430). Vid. GIFREU FONT, J. "Los efectos jurídicos de la anulación del planeamiento urbanístico sobre los actos singulares de aplicación. Especial referencia a los instrumentos de ejecución y títulos administrativos habilitantes dictados a su amparo", en SORIA MARTÍNEZ, G., y BASSOLS COMA, M. (Coords.), Los efectos de la nulidad de los instrumentos de planeamiento urbanístico, Aranzadi, 2017a, pp. 162-163 y 172.

20 Vid. AGOUÉS MENDIZÁBAL, C. (2017: 377). 
reglamentos y que todavía no ha sido destruida; y en el mismo sentido, frecuentemente, su creencia incólume en que el reglamento que aprobó es válido, creencia que incluso puede haberle llevado a interponer el recurso contra la sentencia anulatoria de manera que dejar de aplicarlo -y aplicar la norma anterior que cree derogadapuede ser un contrasentido de consecuencias absurdas e imprevisibles, máxime si finalmente la sentencia anulatoria es revocada. De otro lado, la existencia misma de una sentencia anulatoria que, aunque sin valor aún de cosa juzgada, parece suficiente para debilitar por ahora la presunción de validez del reglamento; el hecho de que, si su actuación es impugnada, los tribunales acogerán probablemente la tesis de la nulidad del reglamento ya plasmada en una sentencia; el dato quizá de que, aunque el art. 72.2 LJCA no da todavía a esa sentencia valor erga omnes, no le niega efectos entre las partes, incluida la propia Administración autora del reglamento. En esta tesitura tan enrevesada, la solución más razonable es que la Administración actúe conforme a lo que crea sobre la validez o invalidez del reglamento. Por tanto, si sigue creyendo en la validez de su reglamento y si por eso impugna la sentencia anulatoria, puede actuar como si fuese válido; puede hacerlo pero a condición de una motivación específica y especialmente detallada que no sólo invoque el art. 72.2 LJCA (y por tanto, el hecho de que la sentencia al no ser firme ni tiene valor general ni cosa juzgada) sino las razones que le llevan, pese a todo, a sostener la validez del reglamento. Esta es la solución que asume muy clara y razonadamente la STS de 30 de enero 2014 (casación 3045/2011; Ar. 802) en la que además reconoce que hay una cierta rectificación respecto a sentencias anteriores:

"Indica el recurso de casación que (...) no procede esperar a la firmeza de la anulación de una disposición general para que la anulación produzca efectos entre las partes afectadas y que dichos efectos se producen desde que la indicada anulación tiene lugar.

Pese a que en alguna ocasión de alguna de nuestras sentencias habría podido deducirse esta doctrina que el propio recurso se cuida de recordar a partir del tenor del artículo 72.2 de nuestra Ley Jurisdiccional, hemos de comenzar ahora indicando que en sí misma considerada no procede acoger esta argumentación que por tanto procede rectificar.

A la Administración -que indudablemente siempre resulta afectada por la anulación de un reglamento propio (o, en su caso, de un instrumento de planeamiento propio, que es también una disposición de carácter general)no le es exigible que venga obligada a aplicar de forma inexorable una resolución carente de firmeza en punto a las resoluciones que deba dictar 
en aplicación de dicho reglamento y le es dable esperar a que la dictada resolución adquiera firmeza a tal efecto.

Es cuestión que queda a expensas de su propia valoración. Y del mismo modo que puede, evidentemente, enderezar su rumbo a partir de la anulación decretada en sede judicial, puede también seguir aplicando el reglamento (a menos claro está que proceda dar el curso correspondiente a la ejecución provisional de la sentencia). Caso de confirmarse la sentencia dictada en instancia, entonces sí tiene forzosamente que enderezar su rumbo inicial; pero, como dicha resolución judicial podría también llegar a revocarse, la Administración podría seguir ajustando sus resoluciones al sentido inicial de sus disposiciones, sin que pueda formularse reproche alguno contra ella por la expresada razón."

Así que, dice, "los efectos resultantes de la anulación de un reglamento no se (comunican) irremisiblemente a los actos dictados en su aplicación sino cuando se produzca la firmeza de la sentencia". Y luego reitera: "la anulación de un reglamento por una resolución judicial carente de firmeza no vincula por sí sola y determina el sentido al que deban ajustarse todas las actuaciones practicadas con posterioridad a aquélla".

Por tanto, la Administración puede ya dar por buena la sentencia anulatoria no firme y no publicada y actuar como si el reglamento o plan fuese nulo y como si hubiera revivido el anterior. Pero puede hacer exactamente lo contrario ${ }^{21}$. Los riesgos que asume con ese comportamiento son muchos pero esa postura no es en sí misma ilícita. Lo será si finalmente se confirma la nulidad del reglamento o plan en la sentencia definitiva. Pero lo será porque habrá que considerar que el reglamento era nulo desde el principio, no porque haya desobedecido una sentencia que todavía, propiamente, no le vinculaba. Todo ello, por supuesto, en el bien entendido, de que no se haya pedido y acordado la ejecución provisional de la sentencia no firme. Y sin perjuicio de que el acto dictado en el ínterin (esto es, entre que se produjo la primera sentencia anulatoria y que se publica el fallo de la que la confirma definitivamente) alcance firmeza, en cuyo caso ese acto devenido firme quedará a salvo en virtud del art. 73 LJCA, como luego se verá.

21 Ésta es también la tesis que finalmente propugnan MUÑOZ MACHADO, S. y CARRO MARINA, M. (2012: 1827), aunque expresándola en términos con los que acentúan que más bien la Administración debe seguir aplicando el reglamento o plan anulado por sentencia no firme que la misma Administración ha recurrido. 


\section{Consecuencias de las sentencias firmes anulatorias de reglamentos en tanto no son publicadas}

Más absurdo sería no tener en cuenta la sentencia firme anulatoria de un reglamento por el mero hecho de que todavía no estuviera publicada ${ }^{22}$. Por eso, porque lo contrario sería absurdo, la jurisprudencia no ha tenido empacho en establecer lo contrario pese a lo que podría desprenderse del tenor literal del art. 72.2 LJCA.

Lo cierto es que el TS tiene establecido que la sentencia firme anulatoria de un reglamento o plan vincula a los tribunales y a la Administración sin esperar a su publicación. Botón de muestra es la STS 645/2017, de 6 abril (casación 1497/2016; Ar. 1670). Se cuestionaba que un ATSJ de Galicia tuvo en cuenta la sentencia que anuló el PGOU de Vigo antes de que fuese publicada. Y la STS contesta:

“... aun siendo ciertos los hechos, el Tribunal de instancia no podía dejar de tomar en consideración la anulación judicial decidida por el TS (...) y sin que, en modo alguno, a estos efectos, la eficacia de la STS pudiera depender de su publicación en el Diario Oficial por parte de la Administración autonómica".

Normalmente el argumento utilizado para burlar lo que parece decir el art. 72.2 LJCA es que éste sólo exige la publicación oficial de la sentencia para que tenga efectos frente a terceros, pero no para que tenga efectos entre las partes, como es la misma Administración que aprobó el reglamento o plan ${ }^{23}$. Pero lo lógico es que también afecte a otras Administraciones ${ }^{24}$.

Ante todo esto, lo difícil es dar algún sentido y algún campo de aplicación a esa exigencia de la publicación de la sentencia que contiene el art. 72.2 $\mathrm{LJCA}^{25}$. Pero sin

22 Sobre esta absurdidad y los efectos perversos a que conduciría, vid. PÉREZ ANDRÉS, A. A. (2000: 170-171) y SANTAMARÍA PASTOR, J. A. La Ley Reguladora de la furisdicción Contencioso-Administrativa. Comentario, Iustel, 2010, p. 734.

23 Por ejemplo, SSTS de 6 de octubre de 2011 (Ar. 7517) y de 2 de marzo de 2015 (casación 3160/2013; Ar. 1782).

24 Lo demuestra la STC 195/2005 que consideró incluso contraria al art. 25.1 CE una resolución sancionadora que aplicó un reglamento declarado nulo por sentencia firme no publicada. En este caso la sanción la había puesto una Administración (un Ayuntamiento) distinta de la autora del reglamento y que, por tanto, no había sido parte en el recurso contra el reglamento. Así que ahí hubo una extensión del efecto de la sentencia no publicada a terceros. Y no cabe duda de que cualquier otra solución habría sido irracional y perversa.

25 REBOLLO PUIG, M. (1998: 532) afirma que lo mejor es entender que la regla, que es como el reverso del deber de publicar los reglamentos y planes y de que su eficacia está condicionada a tal publicación, "únicamente pretende expresar que sólo se produce la expulsión del ordenamiento con valor normativo desde la publicación del fallo, pero ello sin perjuicio de que los efectos propios de una sentencia estimatoria y de una anulación se puedan hacer valer con anterioridad". Así, por ejemplo, "antes de la 
entrar en ello, hay que afirmar que las sentencias firmes anulatorias de reglamentos (o planes) vinculan a los Tribunales y a la Administración que no deben aplicarlos con independencia de que el fallo aún no se haya publicado.

\section{EFEGTOS PARA EL FUTURO DE LA DECLARAGIÓN DE NULI- DAD DE REGLAMENTOS}

\section{La regla geneal}

La eficacia prospectiva entraña que desde que se anula el reglamento (o plan) ya nada podrá basarse en él: ningún derecho ${ }^{26}$ ni deber ni obligación ni potestad.

Si se trata de reglamentos que producen efectos directos ${ }^{27}$, esos efectos cesarán automáticamente con la declaración de nulidad. Por ejemplo, reglamentos que imponen pagos a la Administración o a un sujeto privado sin necesidad de acto administrativo; plan de urbanismo que impone las llamadas vinculaciones singulares o que, comportando una afectación o desafectación tácita, alteran por sí mismos la calificación como demanial o patrimonial de los bienes públicos ${ }^{28}$; etc. Desde la declaración de nulidad ya no habrá ninguna obligación de pago ni vinculación singular ni afectación o desafectación tácita...

Y en todo caso no cabrá ningún nuevo acto jurídico con fundamento en la norma anulada: ningún reglamento (o plan) de desarrollo, acto de ejecución o conve-

publicación los terceros que actúen ilegalmente pero amparados en la apariencia creada por el reglamento anulado no pueden sufrir perjuicios por ello". Certeramente PÉREZ ANDRÉS, A. A. (2000: 169) también entiende que el precepto servirá para que el cómputo del plazo para ejercer la acción de responsabilidad por los daños causados a terceros por el reglamento anulado sólo corra desde la publicación. Vid también ROSENDE VILLAR, C. (2002: 149-150).

26 Aunque eventualmente estuviere inscrito en el Registro de la Propiedad. Vid. GIFREU FONT, J. "La discordancia de los títulos y fincas inscritas en el Registro de la Propiedad con la realidad urbanística derivada de la nulidad de los planes", en SORIA MARTÍNEZ, G., y BASSOLS COMA, M. (Coords.), Los efectos de la nulidad de los instrumentos de planeamiento urbanístico, Aranzadi, 2017b, pp. 256 a 261, que distingue según se trate del derecho al aprovechamiento urbanístico y otros derechos o realidades.

27 Son aproximadamente aquellos a los que aludía el art. 39.3 LJCA/1956: “... disposiciones de carácter general que hubieren de ser cumplidas por los administrados directamente, sin necesidad de previo acto de requerimiento o sujeción individual...".

28 Téngase en cuenta que, conforme a los arts. 5.2.a) de la Ley andaluza 7/1999, de 29 de septiembre, de Bienes de las Entidades Locales, y 8 del estatal Reglamento de Bienes de la Entidades Locales de 1986, los planes urbanísticos alteran la naturaleza de los bienes municipales por medio de una especie de afectación (o, en su caso, desafectación) implícita o tácita, y que, por tanto, la anulación del plan comportará la de esa afectación (o la de la desafectación). De acuerdo con ello, las sentencias anulatorias de planes producen indirectamente la pérdida de la calificación de bienes como de dominio público o, al contrario, que vuelvan a ser reconocidos con tal naturaleza. En ese sentido, véase STSJ de Andalucía, Sala de Málaga, 1780/2016, de 23 de septiembre. 
nio $^{29}$. Y si se hacen deberán ser anulados ${ }^{30}$. El reglamento (o plan) de desarrollo del anulado que se apruebe tras la anulación de éste, será nulo de pleno derecho, puesto que tal grado de invalidez es el único que se acepta para reglamentos (y planes). Y para los actos de aplicación del reglamento (o plan) tras su declaración de nulidad habrá nulidad o anulabilidad según se incurra en alguno de los vicios del art. 47 LPAC o en otros. E igual que no será lícita ni válida ninguna actuación administrativa de aplicación del reglamento (o plan) anulado, tampoco cabrá ninguna resolución judicial basada en el reglamento (o plan) anulado. En todo caso, claro está, esa invalidez (sea nulidad o anulabilidad) necesitará ser declarada formalmente y para ello el acto administrativo o la sentencia que aplicó el reglamento anulado deberán ser recurridos en plazo pues de lo contrario devendrán firmes con las consecuencias a ello inherentes.

Correlativamente, en principio (aunque esto tiene excepciones, sobre todo para los aspectos sancionadores) desde ese momento todos los derechos, deberes, obligaciones y potestades, así como todos los nuevos reglamentos (o planes) de desarrollo y actos de ejecución tendrán que estar asentados en la norma rediviva. Esto vale, desde luego, para los procedimientos administrativos o procesos judiciales que se inicien con posterioridad; pero también para los que ya estuvieran en curso cuando se anuló el reglamento: su resolución, si es que no procede sin más el archivo, no podrá basarse en la norma anulada sino en la revivida.

\section{Posibles matizaciones: consecuencias jurídicas para el futuro de los hechos producidos hasta que se anuló el reglamento}

Pese a la radicalidad con la que hemos afirmado la eficacia pro futuro de las sentencias anulatorias de reglamentos, es posible introducir matizaciones. Tienen dos orígenes.

Unas primeras provienen de que, como ahora se verá, el art. 73 LJCA salva de la ineficacia a ciertos actos anteriores de ejecución de la norma anulada dictados antes de su anulación: al salvar esos actos y al mantener su eficacia para el futuro, también en cierto modo se impide la completa eficacia prospectiva de la anulación del reglamento.

Las segundas matizaciones derivan de que, bajo la aparente vigencia del reglamento nulo, se habrán producidos hechos y realidades a los que el ordenamiento

29 Dudoso es, sin embargo, si, además, los Registradores de la Propiedad pueden denegar inscripciones o anotaciones incompatibles con la declaración de nulidad de un plan. Vid. GIFREU FONT, J. (2017b: 254-255).

30 CARLÓN RUIZ, M. La cuestión de ilegalidad en el contencioso-administrativo contra reglamentos, Civitas, $2^{\text {a }}$ ed., 2005, p. 359. 
anuda ciertas consecuencias que se proyectan sobre el futuro. No serán propiamente efectos jurídicos del reglamento o plan anulado. Serán, más bien, consecuencias jurídicas de ciertos hechos y realidades. Esto no se produce sólo ante la anulación de reglamentos o planes. También los actos o los contratos pueden haber dado lugar a ciertos hechos y realidades y, una vez anulados o declarados nulos, esos hechos y realidades pueden ser presupuesto al que el ordenamiento atribuye determinadas consecuencias. Tampoco aquí se tratará de efectos del acto o contrato nulos sino de consecuencias jurídicas de los hechos o realidades existentes.

Entre esas consecuencias hay -o podría haber- dos especialmente sugerentes ante la anulación de planes. Las ha estudiado González Sanfiel, bajo el rubro de "situaciones fácticas que permanecen tras la anulación"31.

Por una parte se refiere a la clasificación del suelo, sobre todo a la de suelo urbano. En principio, la anulación del plan comporta también la anulación de la clasificación del suelo que realizó: la clasificación será la que estableció el plan revivido $^{32}$. Frente a ello González Sanfiel sostiene que los terrenos que hayan llegado a tener los requisitos legales para ser considerados suelo urbano en ejecución del plan anulado deben ser considerados, pese a esta anulación, suelo urbano. Partiendo de la naturaleza reglada de la clasificación como suelo urbano (reflejada en Andalucía en el art. 45.1 LOUA) y de la celebérrima doctrina del "valor normativo de lo fáctico", afirma que "no es necesario esperar a una modificación del plan para hacer valer aquella naturaleza urbana" y para "el otorgamiento de una licencia aunque el plan no reflejara tal situación" 33 . La idea es atractiva y tiene cierto fundamento. No obs-

31 GONZÁLEZ SANFIEL, A. M. "Límites a la declaración de nulidad de los planes", en LÓPEZ RAMÓN, F., y VILLAR ROJAS, F. (Coords.), El alcance de la invalidez de la actuación administrativa, AEPDA/ INAP, 2017, pp. 435 a 442.

32 Ello por más que sus previsiones hayan quedado desfasadas y que ello tenga "efectos letales". Vid. SORIA MARTÍNEZ, G. "Los efectos de la nulidad de los planes en la clasificación y el régimen jurídico del suelo y la ordenación urbanística", en SORIA MARTÍNEZ, G., y BASSOLS COMA, M. (Coords.), Los efectos de la nulidad de los instrumentos de planeamiento urbanístico, Aranzadi, 2017, pp. 114, 118-119, 123-124 y $127-128$.

33 Invoca a este respecto González Sanfiel la STS de 20 de noviembre de 2000 (casación 7648/1995, Ar. 10491) que, en efecto, aceptó que se otorgara licencia en una parcela en la que se daban los requisitos de suelo urbano pese a que indebidamente había quedado excluida del proyecto de delimitación de suelo urbano. Con todo, es más que dudoso si esta solución, que quizá sea aceptable en el caso de un proyecto de delimitación de suelo urbano, lo es también cuando hay un plan general que no ha clasificado a un suelo como urbano.

Sobre esa base limita los efectos de la declaración de nulidad de los planes: "si algo es urbano, la declaración de nulidad del plan no puede afectar o desconocer esa situación. La nulidad no puede afectar a esa realidad". La clasificación como urbano seguirá "desplegando sus efectos, salvo que la impugnación (y declaración de nulidad) vaya dirigida a cuestionar precisamente esa clasificación”. Las mismas ideas aplica a algunos de los terrenos que necesariamente, por sus características naturales, han de ser suelo no urbanizable en tanto que eso tampoco es discrecional. Con ello, acota las consecuencias de la nulidad del plan y la 
tante, también tiene puntos débiles y su admisión y aplicación suscita más dudas que certezas. Para empezar, esa solución puede dar lugar a la existencia de suelos urbanos que, sin embargo, no tengan una ordenación hasta que un nuevo plan se la dé, por lo que entretanto su reconocimiento como urbano genera problemas de difícil solución $^{34}$. Además, convierte en norma de directa aplicación lo que no es más que un límite a la discrecionalidad del planificador. Y asimismo cabe discutir si el suelo que haya alcanzado los requisitos para ser considerado urbano en ejecución de un plan anulado se beneficia realmente de la doctrina de la fuerza normativa de lo fáctico ${ }^{35}$.

pura y total aplicación del plan reviviscente que "lo único que hará -dice- es complicar más la situación y generar situaciones indeseadas contrarias a esa realidad".

34 Lo reconoce, sin ofrecer una solución suficiente, el propio GONZALEZ SANFIEL (2017: 448). Téngase en cuenta que, como luego se verá, la nulidad de un PGOU arrastra, según la jurisprudencia, la nulidad de todos los planes de desarrollo por lo que, en efecto, ese suelo urbano carecería de regulación.

35 Desde luego, las leyes parecen excluirlo cuando la urbanización se haya realizado de manera completamente ilegal. El art. 21.3 TRLS de 2015 (como antes el 12.3 del TR de 2008), a los efectos de incluir unos terrenos en la situación de suelo urbanizado dice que tiene que estar "integrado de forma legal”. Vid. PAREJO ALFONSO, L. y ROGER FERNÁNDEZ, G. Comentarios al Texto Refundido de la Ley de Suelo (Real Decreto Legislativo 2/2008, de 20 de junio), Iustel, 2009, p. 240. Menos terminante es el art. 45.1 LOUA en cuanto a la clasificación de suelo urbano. Algunas de las "circunstancias" que enumera para que el PGOU clasifique terrenos como suelo urbano sí parten de un proceso legal. Pero al menos la de la consolidación de las dos terceras partes no lo impone expresamente. Tampoco los Tribunales acogen que sean suelos urbanos los urbanizados ilegalmente. Lo sintetiza así la STS de 2 de octubre de 2013 (casación 3970/2010, Ar. 6607):

“... aun en el caso de existencia de los servicios urbanísticos que denotan la pertenencia al urbano, cuando éstos proceden de ejecuciones irregulares, esto es, al margen del planeamiento, no se impone su clasificación como urbanos, ya que se llegaría al resultado, jurídicamente inadmisible, de que las ilegalidades urbanísticas se impondrían por la fuerza de los hechos".

La STS de 16 de noviembre de 2011 (casación 4783/2008, Ar. 2263 de 2012) va más lejos pues, de un lado, afirma, no ya que esos terrenos no tienen que ser clasificados como urbanos, sino que incluso procede la destrucción de los servicios y de los edificios; pero, de otro, entiende que si pasó el plazo para ese restablecimiento de la realidad alterada ilegalmente, sí que debe aceptarse que es suelo urbano pero con servicios y edificaciones fuera de ordenación:

“... cuando se da la circunstancia de que los servicios o la consolidación por la edificación que tuvieran que servir de base para la clasificación del suelo como urbano fueran servicios o edificaciones ilegales, entonces procede, ante todo, que la Administración lleve a cabo el restablecimiento del orden jurídico conculcado, es decir, la desaparición de los servicios o de la edificación; y si por el transcurso del tiempo (...) ya no fuera posible imponer medidas de restauración, ciertamente, el plan debe aceptar la clasificación como suelo urbano pero, tampoco se olvide, el plan debe entonces igualmente declarar tales servicios y edificaciones fuera de ordenación y, desde luego, no cabrá ya obra cualquiera en los edificios existentes y, menos aún, la construcción de nuevos edificios...".

Y a las mismas ideas obedece la STS de 1 de octubre de 2009 (casación 2163/2005, Ar. 950 de 2010). Frente a la alegación de los propietarios de que los terrenos estaban ya urbanizados y consolidados por la edificación y que por ello merecían la consideración de suelo urbano consolidado, dice: 
Por otra parte, propone el mismo González Sanfiel que, pese a la anulación del plan, se mantenga la naturaleza demanial de ciertos bienes. Si más arriba recordábamos que la anulación de un plan comporta la pérdida de efectos de las afectaciones o desafectaciones tácitas que entraña, de lo que ahora se trata es de limitar ese efecto. Lo que sugiere se refiere sólo a las afectaciones (no a las desafectaciones) y únicamente en cuanto los terrenos hayan sido efectivamente objeto de infraestructuras de uso general o servicio público: cuando es anulado el plan, nula e ineficaz será la afectación tácita que contenía, pero habrá una afectación presunta que también admiten las leyes ${ }^{36}$ y que sería suficiente para mantener la naturaleza demanial. Ahora, ésta no derivaría del plan, no sería un efecto jurídico del plan anulado; sería la consecuencia jurídica prevista por el ordenamiento ante una realidad ${ }^{37}$. Aunque es dudoso

“... el planteamiento de la recurrente no puede ser acogido en cuanto alberga la pretensión de que cualquier urbanización, incluso la realizada de forma ilegal, conforma una realidad que debe ser asumida sin más por los autores del planeamiento urbanístico" porque "cuando se ha actuado ilegalmente la Administración no tiene indefectiblemente la obligación de clasificar los terrenos como suelo urbano (...)".

No obstante, esta sentencia sí acepta que los terrenos podían ser considerados suelo urbano no consolidado. De hecho, sigue diciendo: “... pues a efectos de atribuir al suelo la consideración de consolidado que se pretende no basta con cualquier urbanización, incluso la realizada ilegalmente, sino que es necesario que la urbanización se acomode al planeamiento, debiendo por ello asumirse que el planeamiento urbanístico puede imponer una reurbanización de mayor o menor alcance, y que, asimismo, los propietarios han de quedar sujetos al régimen de deberes propio del suelo urbano no consolidado...". La misma idea está en sentencias anteriores como la del TS de 5 de octubre de 1987 (Ar. 8296): "se ha ido creando de una forma clandestina un conglomerado urbano constituido por diversas casas o chalets unifamiliares (...), conglomerado que en la actualidad dispone de los servicios de firme rodado, abastecimiento y vertido de aguas y suministro eléctrico (...); tal situación fáctica, aunque irregular por el sistema de formación, no puede ser desconocido al haber quedado consolidado por la imposibilidad de aplicar a las construcciones realizadas la normativa urbanística que las eliminaría, al haber transcurrido con exceso el tiempo durante el cual tal medida podía adoptarse, lo cual conduce de modo ineludible a estimar que todo el suelo ocupado por esa urbanización de facto (...) tiene carácter urbano (...); actuar de otro modo, sería desconocer el principio de igualdad que debe imperar respecto de todos los ciudadanos y negar a la señora S. lo que la Ley ha reconocido, aunque sea por caducidad, para todos aquellos que, al margen de la ley y sin graves escrúpulos, formaron la agrupación urbana...".

36 Así, el art. 66.2.a) de la Ley 33/2003 de Patrimonio de las Administraciones Públicas dice que surtirá los mismos efectos de la afectación expresa la utilización pública, notoria y continuada por la Administración de bienes y derechos de su titularidad para un servicio público o para un uso general. Más restrictivos son los arts. 5.2.b) de la Ley de Bienes de las Entidades Locales de Andalucía y 8.4.b) del Reglamento de Bienes de las Entidades Locales.

37 GONZÁLEZ SANFIEL busca a esta conclusión un fundamento constitucional puesto que en la misma CE está reconocido el dominio público y su indisponibilidad. Al margen de ello, bien cabría invocar sin más el principio de continuidad de los servicios públicos (incluido el servicio público que entraña el uso común general de ciertos bienes), que es el principio cardinal del Derecho Administrativo. Las calles, los parques, los centros educativos, de transporte, deportivos... existen, son de dominio público y, como tales, al margen de la legislación urbanística y de su consideración por ésta como sistemas generales o dotaciones locales, han de tener la protección que el ordenamiento otorga al demanio y, por ende, mantenerse como tales. 
que la acojan los tribunales ${ }^{38}$, la idea debe explorarse pues tiene fundamento sólido y reduce los efectos más nocivos de las anulaciones de planes.

Sea cual sea el juicio que merezcan estos dos ejemplos concretos sobre la clasificación del suelo y sobre el carácter demanial de ciertos bienes, lo que queríamos poner de relieve es que el efecto para el futuro de la anulación de reglamentos y planes puede tener matizaciones que en gran medida no derivan del mismo reglamento o plan anulado sino de los hechos y realidades surgidos durante su aparente vigencia.

\section{EFEGTOS SOBRE EL PASADO DE LA DEGLARACIÓN DE NU- LIDAD DE REGLAMENTOS. SU EFICACIA RETROACTIVA (EX TUNC)}

\section{La aniquilación de lo realizado en virtud del reglamento anulado}

Como regla general, los efectos de las declaraciones de nulidad de reglamentos (o planes) se retrotraen al mismo momento de aprobación de la norma anulada ${ }^{39}$. Esto, unido a la reviviscencia y carácter erga omnes, entraña que el reglamento (o plan) reviviscente habrá que entenderlo vigente para todos y durante todo el tiempo sin solución de continuidad: no sólo hasta que fue (supuesta y frustradamente) sustituido por el otro y desde la anulación de éste; sino también durante el tiempo que medió entre la aprobación del nulo y su anulación.

Como dijo expresivamente la STS 18 de febrero de 1992 (recurso 1825/1989; Ar. 2293), el reglamento nulo -lo mismo que el plan nulo- sólo tuvo aparente vigencia: "es ineficaz desde su nacimiento y lo sigue siendo durante su aparente vigencia".

38 No me consta que haya jurisprudencia contraria. Pero sí hay sentencias en contra ante un supuesto similar: el de la anulación de licencias. Por ejemplo, SSTS de 22 de diciembre de 2008 (casación 1330/2007; Ar. 365 de 2009) y de 16 de mayo de 2014 (casación 1621/2013; Ar. 3867 y 4354 ) sobre destrucción de una plaza pública, un polideportivo municipal y una biblioteca del Estado. Vid. GÓMEZ-FERRER RINCÓN, R. La imposibilidad de ejecución de sentencias en el proceso contencioso-administrativo, Civitas, 2008, pp. 145 a 175 y 363 a 379; y ESPEJO CAMPOS, A. "Dominio público y BIC como límites a la nulidad en el ámbito urbanístico”, en LÓPEZ RAMÓN, F. y VILLAR ROJAS, F. El alcance de la invalidez de la actuación administrativa, AEPDA/INAP, 2017, pp. 476 a 484. Y es poco probable que los tribunales acojan una solución distinta ante la anulación de planes.

39 En realidad, en esto la situación es igual a la que se produce con la anulación de actos. Y es indiferente que se produzca porque haya causa de nulidad o de mera anulabilidad. La tesis contraria, según la cual la anulación de los anulables no tenía efectos retroactivos, aunque no ha sido inusual, no tuvo nunca justificación y puede ya considerarse completamente superada. Vid. por todos TARDÍO PATO, J. A. "Los efectos ex tunc de la anulabilidad, REDA, no 184 (2017); y "El mito de los efectos ex nunc de la anulación por anulabilidad”, en LÓPEZ RAMÓN, F. y VILLAR ROJAS, F. (Coords.), El alcance de la invalidez de la actuación administrativa, AEPDA/INAP, 2017, pp. 195 a 205. 
También se expresa en términos drásticos, por ejemplo, la STS de 2 de marzo de 2016 (rec. 1626/2015; Ar. 940): la nulidad de pleno derecho de un reglamento "produce efectos ex tunc, originarios, lo que coloca a la norma anulada en una situación equiparable a la inexistencia, esto es, que la nulidad radical conlleva la pérdida de eficacia ex tunc (desde su origen) según el principio enunciado en los aforismos latinos quod nullum est, nullum producit efectum y quod ab initio vitiosum est, nom potest tractu tempore convalescere" ${ }^{40}$.

Por eso, la declaración de nulidad de un reglamento o plan, que tiende a la destrucción de los efectos producidos desde que la norma entró en vigor, no es equivalente a su derogación ${ }^{41}$. Pues cuando hay anulación cabrá, en principio, exigir que la realidad vuelva a la situación que correspondería si no se hubiese aprobado nunca el reglamento o plan que ahora hay que entender como inexistente en todo momento ${ }^{42}$.

Esta eficacia ex tunc se proyecta sobre todo lo realizado en cumplimiento o ejecución del reglamento (o plan) anulado. En especial, pero no únicamente, sobre los actos jurídicos (actos administrativos, contratos, convenios o disposiciones generales) que tuvieran fundamento en él (titulus invalidus non potest aliquem effectum validum operari) aunque sean anteriores a la declaración de nulidad; actos jurídicos que pueden haber

40 Una copiosa jurisprudencia insiste sin desfallecimiento en los efectos ex tunc de la declaración de nulidad de reglamentos y planes. Basten algunas muestras. Así, ante la anulación de un reglamento tributario, dice la STS de 4 de abril de 2012 (casación 5301/2008; Ar. 5177): "Que en los casos de declaración de nulidad de las disposiciones administrativas generales, la nulidad absoluta es la consecuencia ordinaria que el ordenamiento jurídico anuda a su ilegalidad, de manera que la ineficacia de los reglamentos ilegales es una ineficacia ex tunc". Y, ante la nulidad de un reglamento urbanístico, la STS de 30 de enero de 2014 (casación 3045/2011; Ar. 802; FJ 5) explica: “... el Ayuntamiento alude a un supuesto efecto meramente derogatorio del reglamento, pero no parece que esta cuestión se preste a polémica alguna: lejos está de ser así, la nulidad radical produce efectos ab initio o ex tunc (de modo que) si se acuerda la nulidad de una disposición general se han de borrar todos los efectos que hayan podido producirse en el tiempo (...) porque si no la anulación produciría únicamente efectos ex nunc". Ya específicamente para planes de urbanismo, dice, entre otras muchas, la STS de 19 de junio de 2013 (casación 2713/2012; Ar. 5629): "Los Planes Generales de Ordenación Urbana, así como las Normas Subsidiarias que hacen sus veces, tienen la naturaleza de disposiciones generales, por lo que la eficacia de la declaración de su nulidad se retrotrae al mismo instante de haberse dictado...". Véanse también las SSTS citadas en la nota 10.

${ }^{41}$ La derogación, en principio (salvo que el nuevo reglamento se declare retroactivo), sólo tiene efectos para el futuro y no afecta a lo ya producido durante su vigencia; por el contrario, la declaración de nulidad tiende en principio (nótese que sólo hablamos de una tendencia y sólo en principio) a la aniquilación de los efectos producidos. Su equiparación a la derogación lucía en el art. 120.1 de la Ley de Procedimiento Administrativo de 1958: "La estimación de un recurso interpuesto contra una disposición de carácter general implicará la derogación o reforma de dicha disposición, sin perjuicio de que subsistan los actos firmes dictados en aplicación de la misma". Pero ahora, con los arts. 73 LJCA y 106.4 in fine LPAC, aunque se conserve la subsistencia de los actos firmes, ya no quedan restos de esa equiparación entre anulación y derogación.

42 Cosa distinta es que eventualmente esas pretensiones basadas en la nulidad de un reglamento puedan verse enervadas o frustradas por diversas razones: prescripción de acciones, imposibilidad material (por destrucción, por transmisión a un tercero, por incorporación a otro bien...). 
creado obligaciones, incluso ya cumplidas, o transmisiones de propiedad (con o sin expropiación forzosa), impuesto ejecuciones forzosa, sanciones, etc. Pero se proyecta también sobre los efectos directos del reglamento o plan anulado y sobre las actuaciones materiales que tuvieran allí su justificación. Por servirnos de los mismos ejemplos utilizados antes para exponer los efectos para el futuro, digamos ahora que, no sólo no habrá que hacer nuevos pagos en cumplimiento directo del reglamento, sino que los realizados antes de su anulación han de ser considerados sin causa ${ }^{43}$; que no sólo no continuará la vinculación singular de un edificio sino que habrá que entender que no la tuvo en ningún momento; y no sólo habrá que entender que el bien patrimonial convertido en demanial por la afectación tácita del plan anulado vuelve a ser patrimonial sino que lo ha sido siempre (o, a la inversa, que el bien demanial no dejó de serlo en ningún momento).

Ahora bien, todos estos efectos sobre el pasado pueden ser improcedentes si lo mismo que se produjo en virtud de la norma anulada podría o hasta debería haberse producido aunque nunca se hubiese aprobado ésta. O sea, cuando esos efectos encuentren otra justificación (p. ej., directamente en una ley o en el reglamento que el anulado intentó derogar y que hay que entender que estuvo siempre vigente). Esto vale para los actos jurídicos dictados en virtud de la norma anulada pero también para los efectos directos de esa norma anulada (por ejemplo, la sola ley justificaba el pago que el reglamento también consagró y concretó; el reglamento redivivo imponía idéntico deber, igual vinculación singular, etc.).

La idea se ha desarrollado sobre todo en relación con los actos jurídicos de la Administración dictados en ejecución del reglamento (o plan) anulado. Conforme a la jurisprudencia hay que distinguir entre los reglamentos (o planes) de desarrollo del anulado y los actos administrativos de ejecución.

43 Por tanto, será posible exigir la restitución de lo entregado en (aparente) cumplimiento de ese reglamento. Serán prestaciones realizadas solvendi causa (para cumplir el reglamento) que han quedado sin justificación jurídica. Puede tratarse de pagos a la Administración (por ejemplo, ingresos tributarios realizados en virtud de autoliquidación; vid. DOMÉNECH PASCUAL, G. La invalidez de los reglamentos, Tirant lo Blanch, 2002, pp. 315-316) o de pagos entre particulares. Existe a veces una especie de resistencia de los jueces civiles a aplicar esto. Se ve, por ejemplo, en la SAP Barcelona 178/2014, de 21 de mayo (JUR/2014/179317). La SAN de 22 de marzo de 2011 había anulado la Orden Pre/1743/2008 que regulaba el canon digital. Y de acuerdo con ellos unos sujetos que habían pagado a la SGAE ese canon reclamaban su devolución por los efectos ex tunc de la anulación de la Orden y por enriquecimiento sin causa. El Juzgado desestimó la demanda y la SAP lo confirmó. Dijo que no se daban todos los requisitos del enriquecimiento injusto: “... falta, cuando menos (...) la inexistencia de causa" pues "no es controvertido que los pagos se ajustaron a la normativa válida y vigente en el momento en que se realizaron, sin perjuicio de que con posterioridad la Orden de desarrollo fuera anulada" y la jurisprudencia "rechaza el enriquecimiento injusto cuando la atribución patrimonial está amparada por una norma jurídica". Esto parece un error pues no cabe estimar de ningún modo que una norma declarada nula pueda considerarse causa legítima de un enriquecimiento. 


\section{Las normas de desarrollo (y de modificación) del reglamento anulado que se aprobaron antes de la anulación: nulidad}

Cuando se trata de reglamentos de desarrollo de un reglamento anulado la respuesta de los tribunales es inequívoca: el reglamento de desarrollo también es nulo de pleno derecho. Es lo que se ha denominado -y lo hace el propio TS- el "efecto cascada". Ejemplo suministra la STS de 26 de octubre de 2010 ${ }^{44}$. Esto mismo se ha aplicado a los planes de desarrollo del plan anulado lo que conlleva que toda la ordenación urbanística construida sobre el plan anulado se derrumbe como castillo de naipes ${ }^{45}$.

44 Casación 1535/2009 (Ar. 7690). Se había anulado antes un Decreto vasco sobre elecciones en los centros docentes y ahora se trataba del recurso contra una Orden de desarrollo. La STS dice: "Si carece de eficacia y validez el Decreto (...) por haber sido declarado nulo, es obvia la imposibilidad de efectuar un desarrollo del mismo mediante una Orden del Consejero de Educación. Nos hallamos ante la pura aplicación del llamado efecto cascada, es decir que tras la anulación del Decreto..., quedan anulados cuantas normas de desarrollo se amparen en aquél. Estamos ante un claro ejemplo en que la invalidez de una disposición general de superior rango, Decreto, se comunica a la posterior aprobación de un instrumento jurídico de desarrollo, Orden, siendo innegable la relación de causalidad entre el primero y la segunda ulterior. La primigenia invalidez repercute, por tanto, en la validez del instrumento jurídico de desarrollo ya que la disposición inválida no produce efectos".

${ }_{45}$ Vid. CALVO ROJAS, E. (2012: 830). Muestras de esa jurisprudencia, por sólo elegir algunas de las recientes y expresivas, son estas SSTS: - de 19 de junio de 2013 (casación 2713/2012; Ar. 5629): “... con la anulación de la Modificación de las Normas Subsidiarias en el ámbito de (...), el Plan Parcial de desarrollo ha devenido nulo, porque ha quedado privado de cobertura. Los Planes Generales de Ordenación Urbana, así como las Normas Subsidiarias que hacen sus veces, tienen la naturaleza de disposiciones generales, por lo que la eficacia de la declaración de su nulidad (...) comporta igualmente la nulidad de los planes secundarios dictados en su desarrollo, como es el caso de los planes parciales".

- de 8 de octubre de 2013 (casación 2786/2010; Ar. 6916): “... con la anulación de los planes generales (...), el planeamiento secundario o de desarrollo deviene nulo al quedar privado de cobertura. Ello es debido a la naturaleza de los planes como disposiciones generales, por lo que la eficacia de la declaración de su nulidad se retrotrae al mismo instante de haberse dictado, y, en consecuencia, comporta igualmente la nulidad de los planes secundarios dictados en su desarrollo, como sucede con los Planes Parciales".

- de 15 de octubre de 2013 (casación 3765/2010; Ar. 7358): “... resulta improcedente tratar de sostener ahora la legalidad de una norma (pues esa es la naturaleza de los planes de ordenación) como la aquí concernida, que es desarrollo de la que (...) ya ha sido declarada nula por una sentencia firme y que, por tanto, deviene igualmente nula al ser nula la norma de la que trae causa; pues es evidente que el Plan Parcial no puede subsistir sin el planeamiento superior que le servía de cobertura. Así lo ha dicho esta Sala en una jurisprudencia reiterada, que recuerda que la declaración de nulidad de un plan de urbanismo determina que los instrumentos de planeamiento jerárquicamente subordinados al declarado nulo devienen asimismo nulos, justamente por haber quedado desprovistos de sustento normativo...".

- de 3 de marzo de 2015 (casación 4063/2013; Ar. 1951): “... el Acuerdo impugnado (...) en desarrollo del PGOU -hoy definitivamente anulado- aprobaba el Plan Especial de Iniciativa Pública para parcelas destinadas a vivienda protegida en los sectores (...) Desaparecido el Plan General, obvio es que el Plan Especial impugnado carece de soporte jurídico...".

- 1285/2016 de 2 junio (Ar. 3123): la nulidad de un plan "comporta igualmente la nulidad de los planes secundarios dictados en su desarrollo, como es el caso de los Planes Parciales". 
La radicalidad de esta jurisprudencia es chocante ${ }^{46}$. Además, tiene consecuencias graves sobre todo en el caso de los planes de urbanismo ${ }^{47}$. Pero, hoy por hoy, a tal jurisprudencia hay que atenerse.

Además, se aplica igualmente a las modificaciones del reglamento anulado. Reveladora es la STS de 23 de septiembre de $2008^{48}$. Y si esa es la solución del TS para reglamentos ordinarios, con mayor razón hay que aceptarla, y se acepta, para las modificaciones de planes que muchas veces serán estrambóticas separadas del

- STS 2003/2016, de 20 de julio (casación 4402/2012; Ar. 4818): "Los efectos propios de la nulidad plena impiden igualmente que el ordenamiento derivado, planes parciales y de sectorización, puedan tener cobertura en las concretas normas declaradas nulas, como venimos señalando de modo profuso y uniforme en el ámbito urbanístico. En efecto, la nulidad de pleno derecho de la norma de cobertura, es decir, de la norma que es presupuesto necesario de las normas sucesivas derivadas de la misma, acarrea la invalidez de éstas al tratarse de una nulidad ad initio (...( La solución contraria a la expuesta (...), además de infringir lo dispuesto en los arts. 9.3, 24 y 118 CE, 18.1 y 2 LOPJ, 72.2 y 103.4 LJCA y 62.2 y 65 a 67 Ley 30/1992 (...) pretende hacer tabla rasa sobre la diferencias entre la nulidad plena y la mera anulabilidad". Este mismo fragmento transcrito aparece en otras SSTS como las de 28 de septiembre de 2012 (casación 1009/2011; Ar. 9762) o la de 13 de diciembre de 2013 (casación 1003/2011; Ar. 8198).

46 Sobre todo, teniendo en cuenta que, como se ha visto en la citada STS de 3 de marzo de 2015, extiende esa nulidad a los planes especiales cuya dependencia de los planes generales no siempre se produce en los mismos términos. También, en teoría, cabría sostener que, al igual que se dice de los actos dictados en ejecución de un reglamento o plan nulo que pueden ser válidos si encuentran otro fundamento (como se explicará en el siguiente apartado), algunos planes pudieran seguir siendo válidos aunque se anule el Plan General. Ello porque encuentran fundamento y justificación suficientes en las leyes o porque presentan autonomía funcional. Lo ha desarrollado con acierto y aspectos muy sugerentes GONZÁLEZ SANFIEL, A. M. (2017: 442 a 447) y en "El principio de especialidad como límite a la declaración de nulidad del planeamiento", en BASSOLS COMA, M., MENÉNDEZ REXACH, A. y GIFREU, J. (Coords.), El derecho de la ciudad y el territorio. Libro homenaje a Manuel Ballbé Prunes, INAP, 2016. Como mínimo estas ideas justifican que la anulación de planes de ordenación del territorio no afecten a la validez de los planes de urbanismo que no se fundamentan en aquéllos en los que sólo encuentran un límite negativo.

47 De hecho, parece que en el Estado se ha barajado la posibilidad de introducir una norma que matice la radicalidad de este efecto cascada; y ya lo ha hecho alguna ley autonómica. Es el caso de la Ley 4/2017, de 13 de julio, del Suelo y de los Espacios Naturales Protegidos de Canarias, cuyo art. 9.3 dispone: "La invalidez de un plan jerárquicamente superior no afectará por sí sola a los planes de desarrollo e instrumentos de gestión que por razón de especialidad y autonomía en el modelo territorial y urbanístico mantengan una autonomía funcional respecto de aquél".

48 Casación 6967/2005 (Ar. 7233): "Nos hallamos ante la pura aplicación del llamado efecto cascada, es decir, que tras la anulación (...) de los Estatutos, quedan anulados cuantos actos deriven de aquella como es su modificación parcial. Debe insistirse en que no cabe conferir sustantividad propia a la pretendida modificación cuando "modificar" en el uso del castellano es reformar algo. Y no cabe reformar lo que no existe por lo que no se da la pretendida independencia respecto unos Estatutos de 81 artículos que recibe nueva redacción en cuatro de sus artículos y a los que se agrega cuatro nuevos apartados que se adicionaban a otros cuatro artículos. Anulada la inscripción de los Estatutos originarios no cabe pretender la incorporación al Registro de una modificación parcial. Estamos ante un claro ejemplo en que la invalidez (...) se comunica a la posterior aprobación de modificación estatutaria, siendo innegable la relación de causalidad entre la modificación de los Estatutos y los Estatutos primigenios. Aquella invalidez repercute, por tanto, en la validez de la pretendida modificación (...) Lo esencial es que no podía modificarse lo que no existía”. 
resto de las determinaciones del plan ${ }^{49}$. Asimismo se consideran nulos los textos en que se refunde un plan anulado ${ }^{50}$. Tratamiento diferente merecería la revisión de un plan realizada antes de que éste sea anulado ${ }^{51}$.

Cosa distinta es cómo se puede hacer valer esa nulidad de los reglamentos (o planes) de desarrollo (o de modificación) del anulado. Desde luego es posible atacar los dos reglamentos en el mismo proceso ${ }^{52}$. Pero lo que suscita dudas es si, declarada la nulidad del reglamento (o plan) en que se apoya el otro y sólo ella, la del reglamento

49 Así, STS de 13 de junio de 2014 (casación 160/2012, Ar. 3430). Lo enjuiciado allí era una "Modificación puntual no sustancial" de una "Normas transitorias" que fueron anuladas en otra sentencia mientras se tramitaba el proceso. Y en esta STS se lee: "Las partes (...) no discuten realmente las consecuencias anulatorias de las normas transitorias inicialmente aprobadas sobre la indicada modificación puntual no sustancial que a su vez queda afectada, por eso, de nulidad. Este extremo -esto es, que la nulidad de un plan alcanza a las modificaciones de que es objeto- no se pone en tela de juicio". Y de acuerdo con ello dice que "procede (...) ordenar la anulación de la modificación puntual (..) como consecuencia lógica y natural de la anulación decretada en sede judicial del propio plan del que dicha modificación trae causa...". Muy clara es la STSJ de Madrid 181/2000, de 2 de marzo (recurso 878/1995; JUR/2000/304445). Resuelve esta última un recurso contra una Modificación de PGOU aprobada en 1995 en un caso en el que el PGOU modificado había sido anulado por sentencias devenidas firmes en 1998. Y el TSJ lacónicamente dice: "Gozando de la condición de disposición general los Planes de Ordenación Urbana, la eficacia de la declaración de nulidad del Plan General de 1991 se retrotraerá al mismo instante de haberse dictado y, en consecuencia, comportará igualmente la nulidad de las sucesivas modificaciones del mismo, como la que aquí nos ocupa".

50 STS 1425/2016, de 15 de junio: “... esta Sala tiene declarado (...) que en caso de anulación de planeamiento general el fallo declarativo que dispone la nulidad tiene un efecto expansivo (...) sobre el planeamiento secundario (...) Si es necesario tener en cuenta el grado de dependencia de la norma inferior respecto de la superior, igualmente habrá de tenerse en cuenta el grado de vinculación de dos normas de idéntico rango cuando (...) se encuentran en íntima conexión. En el presente caso, la posterior Orden del (...) relativa a la toma de conocimiento del Texto Refundido del Plan General (...) se encuentra vinculada a la anterior Orden (...) por la que se aprobó definitivamente la Revisión, de forma que anulada ésta (...) aquélla deviene igualmente nula al ser nula la norma de la que trae causa, siendo evidente que la disposición que se limita a tomar conocimiento del Texto Refundido de un plan no puede subsistir si se anula la norma que le servía de fundamento y a la que se encuentra indefectiblemente unida . Así lo tiene declarado esta Sala en sentencias de 17 de julio de 2012 (casación 5732/2011) t 26 de octubre de 2012 (casación 4139/2010)...".

51 Para este caso, sí puede mantenerse como regla general la validez de la revisión pese a la posterior declaración de nulidad del plan revisado. Así lo sostiene SORIA MARTÍNEZ, G. (2017: 127): "Podrá haber $(. .$.$) parte de la innovación que no sea válida, en cuanto, por ejemplo, se remita al plan nulo (...) pero$ cuando no haya tal relación sino una nueva normativa que se define con autonomía, al no depender del plan nulo, será válida (...) porque no se trata de un planeamiento $<<$ derivado $>>(\ldots)$ sino de un $<<$ nuevo $>>$ planeamiento...".

52 Es lo que, por ejemplo, sucedía en el caso de la citada STS de 8 de octubre de 2013 (casación 2786/2010; Ar. 6916). Decía la sentencia recurrida: "Será de recordar que (...) nos hallamos ante una impugnación directa de dos figuras de planeamiento urbanístico, una de planeamiento general y otra de planeamiento derivado". Y en ese contexto afirmaba que "si prospera y concurre la nulidad de la figura de planeamiento general de suyo y por consecuencia carece de cobertura jurídica la figura del planeamiento parcial determinándose su nulidad”. Así que el fallo podía y debía anular los dos planes. 
de desarrollo hay que aceptarla sin más, esto es, sin necesidad de una declaración expresa de la nulidad. Y, caso de que se busque una declaración expresa de la nulidad de ese reglamento de desarrollo es dudoso si ello requiere un proceso judicial o de un procedimiento administrativo ad hoc o si cabe hacer esa declaración en ejecución de la sentencia que anuló el plan general.

\section{Los actos administrativos de ejecución del reglamento anulado: validez, nulidad o anulabilidad según los casos}

En principio, las consecuencias de la declaración de nulidad de un reglamento o (de un plan) sobre los actos dictados en su aplicación durante el periodo de su aparente vigencia, dados los efectos retroactivos de la declaración de nulidad, son estos:

- Si el acto encontrase cobertura plena en otra norma distinta de la anulada (por ejemplo, directamente en la Ley; o en un reglamento o plan superior; o en el reglamento o plan redivivo) podrá ser considerado válido. Tendría, acaso, un defecto de motivación en tanto que hubiera invocado la norma anulada y debiera haber invocado otra; pero eso normalmente no se considerará vicio invalidante, al menos, no en este tipo de supuestos.

- Si el acto perdiese su fundamento porque sólo se lo daba la norma anulada, no sería conforme con el ordenamiento jurídico. Por tanto, ese acto devendría inválido (en realidad, lo sería desde su origen ${ }^{53}$ ). Su grado de invalidez dependería de si ahora, prescindiendo de la norma anulada que lo fundamentó, sus vicios encajasen en alguno de los supuestos del art. 47.1 LPAC, en cuyo caso sería nulo de pleno derecho, o no encajasen en ninguno de ellos, en cuyo caso sería sólo anulable. Como normalmente se admite que la regla general en nuestro Derecho es la anulabilidad de los actos administrativos viciados, partiendo de esa regla general, lo mismo habría que decir de la invalidez de los actos ilícitos por anulación del reglamento o plan que les daba sustento. Por tanto, como regla general serían anulables y sólo en algunos casos nulos de pleno derecho ${ }^{54}$.

53 Por eso no se trata propiamente de un supuesto de invalidez sobrevenida sino originaria. Así lo explica certeramente CANO CAMPOS, T. La invalidez sobrevenida de los actos administrativos, Civitas, 2004, pp. 277-278, que, no obstante, apunta algunas excepciones que no afectan a lo que aquí analizamos. Vid, no obstante, GONZÁLEZ SANFIEL, A. M. "Invalidez sobrevenida de los actos de aplicación del planeamiento urbanístico nulo", en Estudios sobre el planeamiento territorial y urbanístico, Tirant lo Blanch, 201 1, pp. 285 y ss.

54 En cualquier caso un reglamento o plan posterior, aunque fuese idéntico al anulado y pudiera dar ahora cobertura a actos iguales a los que aplicaron aquél, no serviría para dar validez a aquellos. Serán necesarios nuevos actos. Vid. DE COMINGES CÁCERES, F. (2017: 53-54). 
Es todo esto lo que mantiene la doctrina dominante ${ }^{55}$. También lo que consagra el TS: admite que los actos dictados en aplicación del reglamento o plan anulado pueden ser válidos ${ }^{56}$; y para los casos en que no se sostenga la validez, no afirma

55 A este respecto es capital el estudio de GÓMEZ-FERRER MORANT, R. "Nulidad de reglamentos y actos dictados durante su vigencia”, REDA, no 14 (1977), pp. 394 y ss. Su tesis, según la cual los actos dictados en aplicación de un reglamento anulado pueden ser válidos, anulables o nulos según las circunstancias, con adición de algunos argumentos y a veces con matices, es la asumida por la mayoría de la doctrina. Véanse CANO CAMPOS, T. (2004: 261 a 264); CARLÓN RUIZ, M. (2005: 363); ESPEJO MEANA, M. R. "Nulidad de reglamentos: efectos jurídico-materiales de la sentencia sobre los actos dictados en su aplicación. Comentario a la STS de 21 de julio de 1991 (Ar. 5594)", RAAP, nº 12 (1992), pp. 136 y ss.; JORDANO FRAGA, J. "Efectos de la invalidez de los reglamentos en el ámbito tributario: el caso del canon de los puertos deportivos de Andalucía”, en LÓPEZ RAMÓN, F. y VILLAR ROJAS, F. (Coords.), El alcance de la invalidez de la actuación administrativa, AEPDA/INAP, 2017, p. 505; PÉREZ ANDRÉS, A. A. (2000: 223); y TRAYTER JIMÉNEZ, J. M. (1996: 396). También DOMÉNECH PASCUAL, G. (2002: 332 a 352), acepta diversas posibilidades y grados de invalidez, aunque finalmente los efectos los hace depender de una ponderación en cada caso entre las exigencias del principio de legalidad y del principio de seguridad, ponderación en la que valora el vicio que aqueje al reglamento, los intereses lesionados, la confianza generada por la apariencia del reglamento, los daños que ocasiona defraudarla... Aplicándolo a la nulidad de planes de urbanismo y con observaciones interesantes que acogemos, GONZÁLEZ SANFIEL, A. M. (2017: 419-420).

Los autores que ofrecen una respuesta única, difieren en esa respuesta. Para algunos, se tratará en todo caso de actos anulables; en esa dirección LAVILLA ALSINA, L. "La revisión de oficio de los actos administrativos", RAP, no 34 (1961), p. 53, y CALVO ROJAS, E. (2012: 831). Y para otros de actos nulos; así lo afirman BELADÍEZ ROJO, M., Validez y eficacia de los actos administrativos, Marcial Pons, 1994, pp. 327 y 333, y FERNÁNDEZ SALMERÓN, M. El control jurisdiccional de los reglamentos. Procedimiento administrativo, proceso judicial y potestad reglamentaria, Atelier, 2002, p. 483. Pero los argumentos que ofrecen no resultan suficientes para contradecir la tesis mayoritaria, a la que nos sumamos, según la cual los actos de aplicación del reglamento o plan anulado serán, según los casos, válidos, anulables y excepcionalmente nulos.

56 Lo explica la STS de 30 de enero de 2014 (casación 3045/2011; Ar. 802): “... puede suceder que el acto de aplicación (por ejemplo, el otorgamiento de una licencia) pudiera encontrar todavía una cobertura propia, si no en la norma (o el plan) de la que directamente procede y a cuyo socaire se aplica, acaso en alguna otra norma asimismo integrante del mismo ordenamiento jurídico. De esta manera, podría justificarse la falta de comunicación a los actos posteriores de las consecuencias anudadas a la anulación de la norma reglamentaria bajo cuya cobertura se dictan aquéllos". Y lo ejemplifica la STS de 12 de marzo de 2015 (casación 1881/2014; Ar. 3626). Esta sentencia mantuvo una serie de actos de gestión (proyecto de urbanización, de reparcelación, cuotas...), pese a que se basaban en un plan anulado, porque eran firmes. Pero lo que ahora interesa es que también los mantiene porque, aunque anulado el plan parcial que ejecutaban, encontraban cobertura en el planeamiento general, en concreto en unas Normas Subsidiarias: "la nulidad no alcanza a las previsiones del planeamiento general (...) es decir, se mantiene para las actuaciones desarrolladas en ejecución del planeamiento de desarrollo la cobertura que directamente otorga este instrumento urbanístico de carácter general". En relación con una licencia, véase también la STS de 26 de abril de 2005 (casación 3919/2002). Igualmente son significativos los AATS de 31 de mayo de 2005 (piezas de suspensión 391/1999 y 30/2000; JUR 2005/223622 y 223623). Se había impuesto sanciones en aplicación de un reglamento; después se anuló por sentencia ese reglamento por defecto de procedimiento; y los sancionados pidieron que se requiriese a la Administración para que se abstuviera de realizar actos dirigidos a cobrar la multa. El TS lo denegó porque las sanciones no se apoyaban sólo en aquél reglamento sino también en ciertos artículos de la Ley de Estatuto del Vino y en su Reglamento general, "preceptos que 
siempre la nulidad de pleno derecho sino que acepta que puedan ser meramente anulables ${ }^{57}$. Habrá que analizar caso por caso para adscribirlos a una u otra situación pero, en principio, cabe mantener, conforme a la más estricta ortodoxia, que sólo excepcionalmente serán nulos de pleno derecho; como regla general serán anulables.

Lo dicho vale para todo tipo de actos de ejecución del reglamento anulado. Y para los muy diversos géneros de actos de aplicación de los planes anulados: licen$\operatorname{cias}^{58}$, proyectos de urbanización, estatutos y bases de actuación de juntas de com-

sirven de cobertura normativa a (las sanciones) por lo que no se aprecia que la anulación de (el reglamento) determine por sí sola la exclusión de la sanción o sanciones impuestas". O sea, que las sanciones eran válidas aunque se dictaron en aplicación de un reglamento declarado nulo.

57 Dice la STS 1997/2016, de 6 de septiembre (casación 3365/2014; Ar. 5776) “... no siempre será la nulidad (...) la respuesta procedente respecto de los actos dictados en aplicación de una disposición nula". La respuesta más completa está en la STS, ya añosa pero que conserva plena validez y constituye referencia obligada, de 12 de julio de 1991 (recurso 5740/1990; Ar. 5594). Explica que en relación con los actos de aplicación de un reglamento anulado "pueden darse las siguientes hipótesis: 1) que los actos incurran en alguno de los casos de nulidad absoluta...; 2) que los actos sean anulables por infracción manifiesta de la Ley...; 3) que los actos sean anulables pero no incurran en la comentada infracción manifiesta, supuesto en que la Administración, y sólo ella, puede declararlos lesivos y proceder a su impugnación contenciosa...; y 4) que los actos sean válidos y legales, en cuyo caso quedarán plenamente subsistentes". La distinción que hace esta STS entre actos anulables con o sin infracción manifiesta de la Ley obedecía a que entonces la Ley de Procedimiento Administrativo de 1958 establecía diferentes procedimientos de revisión según hubiera o no esa infracción. Hoy no se hace esa diferenciación y en ese punto la STS transcrita ha quedado obsoleta. Pero en todo lo demás sigue siendo correcta. Incluso en su afirmación, que ahora hay que extender a todos los casos de anulabilidad incluso con infracción manifiesta de la Ley, de que para conseguir su anulación la Administración, y sólo ella, tendrá que declararlos lesivos y después recurrirlos ante la jurisdicción contencioso-administrativa (art. 107 LPAC).

Conste que hay sentencias que se apartan de la tesis que hemos expuesto como dominante y correcta. Es el caso de la STS de 23 de septiembre de 2003 (casación 380/1999; Ar. 7789). Acepta que los actos de aplicación de un reglamento anulado pueden ser válidos si tienen cobertura en otra norma. Pero si no es así sólo concibe la nulidad, nulidad, dice, que "no sólo procede en los casos contemplados en el art. 62.1 (de la Ley 30/1992, igual al art. 47.1 LPAC) sino también cuando el acto ha perdido cualquier cobertura en el ordenamiento jurídico".

58 Licencias urbanísticas de todo tipo, no sólo las de obras. Ejemplo de ello es la STSJ de Madrid $487 / 2017$ de 28 junio (RJCA $2017 \backslash 674)$ que resolvió un recurso contra tres licencias de obras de nueva planta y dos licencias de primera ocupación dadas en virtud de un PGOU anulado (sin él, las licencias estaban otorgadas sobre suelos no urbanizables de especial protección). Y, como se trataba de licencias no firmes, dice que la nulidad del PGOU "se comunicará irremisiblemente a la licencia"; así que, "tras la declaración de nulidad del planeamiento que servía de cobertura a las (...) licencias de obra de nueva planta impugnadas, nos encontramos con unas licencias que autorizan la ejecución de obras de edificación sobre suelo no urbanizable de protección". Luego se ocupa de las licencias de primera ocupación y las declara nulas por ser nulas las de obras. 
pensación ${ }^{59}$, proyectos de compensación o reparcelación ${ }^{60}$, liquidaciones de cuotas, órdenes de restablecimiento de la legalidad o actos de legalización de edificios inicialmente ilegales ${ }^{61}$. También vale para las sanciones impuestas en aplicación del reglamento anulado: éstas, en principio, quedan afectadas por la declaración de nulidad del reglamento en que se apoyen en los términos vistos para los demás actos, incluso aunque estén completamente ejecutadas ${ }^{62}$.

59 Es el caso de la STS de 14 de julio de 2004 (casación 2065/2002; Ar. 5602) que entiende procedente la estimación del recurso interpuesto en su momento contra al acuerdo aprobatorio de las bases de actuación y estatutos de una junta de compensación que se apoyaba en un plan declarado nulo por sentencia: "si es nula la expresada Modificación puntual y nulo igualmente el Plan Parcial, también lo serán los actos de desarrollo, en este caso los Estatutos y las Bases de actuación de la Junta de Compensación (...) dado que los mismos no tienen, o al menos no se ha acreditado, amparo o cobertura en otro Plan superior".

60 Dice, por ejemplo, la ya aludida STS de 17 de septiembre de 2009 (casación 4924/2005; Ar. 822 de 2010) que anulada "la modificación puntual del Plan General de Calahorra por causas sustantivas, al incurrir en un importante déficit de espacios libres" es obvio que "conlleva, inexcusablemente, la alteración de la ordenación detallada del ámbito, y como consecuencia de ello, de las propias determinaciones del Proyecto de Compensación en cuestión, al que se le transmitió el mismo vicio de nulidad, sin que pudiera en ningún caso "conservarse". Y lo mismo se observa en la STS de 12 de mayo de 2015 (Casación 1920/2013; Ar. 2862): no cabe "mantener cualquier asomo de duda sobre la nulidad radical de que adolece el Plan (...) y, por ende, de los actos derivativos de desarrollo o ejecución como el que nos ocupa ahora que encontraba en aquél su cobertura formal, en el contexto del principio de jerarquía entre instrumentos de planificación y desarrollo". Ello le lleva a la anulación del proyecto de reparcelación "toda vez que (...) se trata de una actuación de desarrollo de un plan de ordenación (...) que no puede servirle de cobertura y justificación al haber sido declarado nulo de pleno derecho...". Todo esto hay que entenderlo, como iremos aclarando para todos los casos, en el sentido de que la reparcelación no firme podrá ser anulada pero necesita una impugnación y una declaración de nulidad sin que baste la declaración de nulidad del plan en que se base. GIFREU FONT, J. (2017b: 260) lo pone de relieve y saca la consecuencia registral: “... la mera nulidad el Plan no supone la necesaria nulidad de la reparcelación. Se podrá declarar por vía de recurso (...) pero no es automática. En consecuencia, no cabe la cancelación de asientos o la inscripción de otros con la sola acreditación de la nulidad del Plan...".

${ }_{61}$ De esto se ocupó la STS de 23 de noviembre de 1999 (casación 2278/1994; Ar. 9767) ante una legalización a posteriori de 120 viviendas, legalización que se hizo en virtud de un plan después anulado. La sentencia simplemente afirma que procede su anulación como en todos los casos de "actos que no hayan obtenido firmeza, al estar pendiente de resolución un recurso interpuesto contra ellos...".

62 SANTAMARÍA PASTOR, J. A. (2010: 736-737), pone de relieve lo absurdo del último inciso del art. 73 LJCA si se entendiera que las sanciones quedan siempre exceptuadas de la regla establecida inmediatamente antes de modo que hasta las resoluciones sancionadoras no firmes resultasen intocables si estaban completamente ejecutadas. Pero no es así como debe interpretarse el precepto: las sanciones no firmes quedan sometidas a la regla general y se verán afectadas por la sentencia anulatoria del reglamento aplicado aunque estén ejecutadas completamente; sólo para las resoluciones sancionadoras firmes se establece una excepción, como veremos después.

Por tanto, el recurso que ya estaba interpuesto o el que todavía se pueda imponer por quedar plazo cuando se anula el reglamento habrá que resolverlo sobre la base de la total inaplicabilidad de éste y, en su caso, aplicando la norma resucitada. Si no es del todo así es por las singularidades del Derecho sancionador: no se admite que al resolver el recurso se cambie el fundamento de la sanción y, por tanto, que allí se sustituya la norma reglamentaria invocada en la resolución sancionadora (el reglamento anulado) 
En cualquier caso, si esos actos son inválidos (tengan vicios de nulidad o de anulabilidad) deberán ser impugnados para que realmente pierdan su eficacia. Si no son impugnados en plazo devendrán firmes con las consecuencias inherentes a ello. De nada de lo expuesto -ni tampoco de una supuesta interpretación a contrario del art. $73 \mathrm{LJCA}^{63}$ - se desprende que los actos administrativos no firmes que aplicaron el reglamento anulado haya que entenderlos inválidos automáticamente y que la Administración o los particulares puedan desentenderse de ellos sin mediar ninguna declaración que pronuncie su nulidad (si son considerados nulos de pleno derecho) o los anule (si se consideran anulables). Si ya estaban impugnados y sólo se está pendiente de resolución judicial o administrativa, nada hay que añadir. Pero si no estaban impugnados y todavía se está en plazo para ello, habrá que impugnarlos ${ }^{64}$. Y si no se hace así devendrán firmes por mucho que ahora haya funda-

por otra que sí le dé fundamento válido. Esto obedece a causas específicas (el derecho a conocer la acusación, las especiales garantías para asegurar al máximo el derecho de defensa...). Lo cierto es que en estos supuestos lo que procederá en todo caso será simplemente anular la sanción (sin posibilidad de buscarle un fundamento alternativo) y, si acaso, si no ha prescrito la infracción, empezar un nuevo procedimiento sancionador en el que desde el principio se sostenga la acusación con la invocación de la norma válida. Ejemplo de todo ello, en relación con la anulación de planes urbanísticos, ofrece la STSJ de Andalucía/ Sevilla 1029/2014, de 20 de noviembre (apelación 444/2014; JUR 2015/129415). Un Ayuntamiento impuso una sanción por realizar una construcción en contra de la ordenación establecida en un PGOU, plan que, entretanto se resolvía el recurso interpuesto contra aquélla, había sido anulado. Aunque la STSJ recuerda el art. 73 LJCA, dice que "no es éste nuestro caso pues: de una parte, no nos encontramos ante actos administrativos firmes (...); y, de otra, estamos ante actos de naturaleza sancionadora no ejecutados y en los que la nulidad del PGOU comporta (...) la falta de cobertura jurídica a partir del mismo hecho de los hechos objeto de sanción”. Aun así, el Ayuntamiento sostenía que, aunque el PGOU había sido declarado nulo, la construcción vulneraba igualmente las Normas Subsidiarias anteriores que resultaron reviviscentes tras la anulación del PGOU. Pero el TSJ afirma que no cabe confirmar la sanción con ese nuevo apoyo por el carácter revisor de la jurisdicción contencioso-administrativa: lo que ésta controla es el acto impugnado "adoptado con base en las previsiones contenidas en aquel PGOU" anulado. Dice que lo que podría hacer el Ayuntamiento es iniciar un nuevo procedimiento sancionador en aplicación de aquellas Normas Subsidiarias con derecho de defensa y plenitud de garantías, tarea que "no puede ser realizada en el marco de un procedimiento jurisdiccional en sustitución de competencias que le corresponden $(. .$. a la Administración".

63 Como el art. 73 LJCA -que estudiaremos después- se refiere a los actos firmes, en alguna ocasión se ha propuesto una interpretación sensu contrario según la cual las sentencias anulatorias de reglamentos si afectarían "por sí mismas" a la eficacia de los actos no firmes que aplicaron el reglamento. Así lo hace expresamente CARLÓN RUIZ, M. (2005: 365), y sobre todo FERNÁNDEZ SALMERÓN, M. (2002: 398 a 401), aunque luego rodea su afirmación de tales condiciones que rebaja mucho las consecuencias más peligrosas de su tesis. Hay que rechazar radicalmente tal interpretación: ni la lógica y literalidad del art. 73 LJCA la sustentan; y causaría estragos y total inseguridad. Hay que afirmar, como lo hace por ejemplo PÉREZ ANDRÉS, A. A. (2000: 224), que contra esos actos no firmes es "imprescindible" su impugnación.

64 Cuestión distinta es si tales actos no firmes han de ser impugnado mediante recursos ordinarios autónomos (en los que la sentencia anulatoria juega simplemente con el efecto prejudicial de la cosa juzgada) o si también cabe combatirlos en la ejecución de la sentencia anulatoria del plan, como frecuentemente se hace por la vía del art. 103.4 y 5 LJCA. 
mentos sólidos para pensar que son anulables o incluso nulos al faltar el reglamento o plan que les daba sustento. Por tanto, lo que aporta a este respecto la sentencia anulatoria del reglamento (o plan) y sus efectos retroactivos es un fundamento en el que basar el recurso que proceda y la resolución que en respuesta se dicte; un fundamento, además, incuestionable por la cosa juzgada. Pero el recurso y la resolución de éste serán necesarios. No hay ninguna razón para negar a esos actos su presunción de validez, ejecutividad y ejecutoriedad ${ }^{65}$. Al contrario, lo que hemos expuesto, en tanto que demuestra que todavía es posible que el acto sea válido (por encontrar una cobertura en otra norma) o que sea anulable, justifica que sólo con una declaración formal de nulidad o con una anulación se destruya su presunción de validez, su ejecutividad y su ejecutoriedad. Y esto lo tiene declarado el TS: por ejemplo, en su sentencia de 7 de marzo de 2012 (casación 4941/2009; Ar. 4907) se lee: "cualquier pronunciamiento al respecto requerirá la impugnación de los concretos actos de aplicación".

\section{EXGEPGIONES A LA RETROACTIVIDAD DE LA ANULACIÓN DE REGLAMENTOS. EL ARTÍCULO 73 LJCA}

\section{E1 art. 73 LJGA y preceptos concordantes. Naturaleza y ámbito de aplicación}

Guanto acabamos de exponer como pura consecuencia de la teoría general de la nulidad dominante es el punto de partida. Pero sobre él hay que introducir correcciones notables que derivan en la actualidad del art. 73 LJCA.

En parte una idea similar lucía ya en el art. 120.1 LPA/58. En su regulación de los recursos administrativos -téngase en cuenta que entonces cabían recursos administrativos directos contra reglamentos- ese art. 120.1 disponía que "la estimación

Lo que sí es seguro, desde luego, es que estos actos administrativos de aplicación del reglamento o plan también podrían haber sido impugnados en el mismo recurso contra el reglamento o plan. Ello tanto por interponer un recurso indirecto contra el reglamento o plan (en cuyo caso, la estimación ya comportará antes que nada la anulación del acto) como por interponer un recurso directo al que se acumule una pretensión de nulidad del acto, ya sea desde el principio (art. 34 LJCA), ya sea después (art. 36.1 LJCA). En cualquiera de estos supuestos todo se desarrollará de forma sustancialmente igual a la explicada: no habrá primero una anulación del reglamento o plan y después del acto sino que todo se resolverá en la misma sentencia. Y por lo que aquí nos incumbe el acto de aplicación del reglamento o plan nulo será anulado sin que el art. 73 LJCA sea de aplicación ni remotamente suponga un obstáculo a ello.

65 Como dice GIFREU FONT, J. (2017a: 179), "por el principio de presunción de validez de los actos administrativos, los dictados en aplicación del plan son válidos y eficaces (...) incluso con la nulidad firme del plan, y esa validez y ejecutividad se mantienen mientras no se produzca su declaración de ilegalidad". Y en p. 180 aclara que los que no habían alcanzado firmeza cuando se anuló el plan deberán ser impugnados en el plazo que todavía quede so pena de ganar firmeza. 
de un recurso interpuesto contra una disposición de carácter general implicará la derogación o reforma de dicha disposición, sin perjuicio de que subsistan los actos firmes dictados en aplicación de la misma"66.

No existía nada semejante en la LJCA de 1956 para los recursos contencioso-administrativos contra reglamentos. Pero los tribunales entendieron que la regla del art. 120.1 LPA/58 también era aplicable en este ámbito y que determinaba los efectos de sus sentencias anulatorias de reglamentos y planes ${ }^{67}$.

Ley 30/1992 de Régimen Jurídico de las Administraciones Públicas y del Procedimiento Administrativo Común en su redacción originaria no contenía ninguna regla al respecto, lo que en realidad era resultado de que no preveía ni recursos administrativos ni revisiones de oficio contra reglamentos ${ }^{68}$. Pero tras su reforma por Ley 4/1999, al hilo de su regulación de la revisión de oficio, paso a decir en su art. 102.4: "Las Administraciones públicas, al declarar la nulidad de una disposición o acto, podrán establecer, en la misma resolución, las indemnizaciones que proceda (...); sin perjuicio de que, tratándose de una disposición, subsistan los actos firmes dictados en aplicación de la misma". Exactamente lo mismo y en idénticos términos aparece ahora en el art. 106.4 LPAC.

Por otro lado, en el Texto Refundido de la Ley de Haciendas Locales hay un precepto que, con algún matiz, refleja la misma idea. En concreto, su art. 19, bajo el rubro "recurso contencioso-administrativo", dice en su apartado 2:

"Si por resolución judicial firme resultaren anulados o modificados los acuerdos locales o el texto de las ordenanzas fiscales, la entidad local vendrá obligada a adecuar a los términos de la sentencia todas las actuaciones que lleve a cabo con posterioridad a la fecha en que aquélla le sea notificada. Salvo que expresamente lo prohibiera la sentencia, se mantendrán los actos firmes o consentidos dictados al amparo de la ordenanza que posteriormente resulte anulada o modificada" 69 .

66 Aunque, en efecto, había una salvedad en favor de los actos firmes, como en el art. 73 LJCA, aparecía en el contexto de una asimilación de la declaración de nulidad a la derogación de la que ya, como explicamos antes, no quedan ni vestigios.

67 Es más, está ahí el origen de la jurisprudencia que todavía hoy se mantiene y acaso el de algunos equívocos a los que daba pábulo esa referencia a la "derogación". Lo cierto es que todavía en la actualidad se siguen dictando sentencias que recuerdan aquel art. 120.1 LPA/58 y que invocan las sentencias que lo aplicaron, lo que resulta una erudición que no contribuye a la claridad ni al correcto enfoque.

68 No obstante, la misma regla siguió aplicándose incluso "de modo bastante más riguroso", según dice GÓMEZ DÍAZ, A. B. "La eficacia de las sentencias contencioso-administrativas: entre la dogmática y la ingeniería judicial", RAP, no 144 (1997), p. 265.

69 En general se entiende que este art. 19 del TRLHL sólo establece lo mismo que el art. 73 LJCA. Por ejemplo, la STS de 7 de marzo de 2010 (casación 4941/2009; Ar. 4907), tras sintetizar el régimen que 
Una primera idea debe destacarse de ese origen en la LPA de 1958 y de su permanencia ahora en el art. 106.4 LPAC: esta salvedad en favor de los actos firmes no es peculiar de las sentencias anulatorias de reglamentos sino común a cualquier pronunciamiento de nulidad de reglamentos, aunque se contenga, no en una sentencia, sino en una resolución administrativa. Además, no se proyecta sólo sobre procesos sino también sobre todo género de relaciones jurídicas. Así que, propiamente hablando, aunque se contenga en una ley procesal, como es la LJCA, no es una norma procesal sino jurídica sustantiva ${ }^{70}$.

Por otra parte, tanto antes como después del art. 73 LJCA, los tribunales reiteran que se trata de una moderación de la eficacia ex tunc de los pronunciamientos de nulidad, de una regla que "atempera" esa eficacia retroactiva por razones de seguridad jurídica (por tanto, ancladas en el art. 9.3 CE) de las declaraciones de nulidad, sean judiciales o administrativas. Esa justificación en el principio constitucional de seguridad jurídica no puede perderse de vista.

De todos los efectos retroactivos de las anulaciones de reglamentos que hemos visto, el art. 73 LJCA sólo salva los que se proyectan sobre actos y sentencias firmes. No, pues, los relativos a los reglamentos de desarrollo o los que produjo directamente el reglamento. Ni los reglamentos ni esos efectos directos son nunca firmes ni en cualquier caso el art. 73 LJCA alude a ellos. Así que nada hay que añadir ni matizar ahora en cuanto a la nulidad de los reglamentos de desarrollo. Ni tampoco en cuanto a la aniquilación de los efectos directos (sin acto administrativo) del reglamento anulado ${ }^{71}$. Nada salvo que, a su vez, los haya confirmado una sentencia firme.

se desprende del art. 73 LJCA, dice: "El art. 19 LHL no altera, como regla general, el régimen expuesto de mantenimiento de los actos firmes o consentidos dictados al amparo de la ordenanza que posteriormente resulta anulada...".

$70 \quad$ En contra, PÉREZ ANDRÉS, A. A. (2000: 205).

71 Respecto a ello y precisamente en relación con la vinculación singular establecida por un plan (por el plan directamente, sin acto administrativo de ejecución) lo dice la STS STS 1253/2017, de 13 julio (Ar. 3226): el art. 73 LJCA “... no resulta de aplicación, dado que la vinculación singular no nace de ningún acto de aplicación del PGOU declarado nulo, sino del propio contenido del Plan, de lo que se deduce que declarada su nulidad, la regulación que imponía tal vinculación ha desaparecido con él". Sólo hay que matizar que el art. 73 LJCA sí que puede resultar de aplicación en tanto que salva, no ya a los actos administrativos firmes, sino a las sentencias firmes. Si hubiera con anterioridad a la anulación del reglamento alguna sentencia aplicándolo (por ejemplo, condenando a un sujeto a un pago en virtud del reglamento luego anulado) y hubiera ganado firmeza, ésta también sería intocable y no afectada por la que después anule el reglamento. De inmediato volveremos sobre ello. Pero si no hay ni acto ni sentencia firme, no encontrando ese límite del art. 73 LJCA, hay que aplicar la regla general que, según sabemos, es la de la eficacia retroactiva de la declaración de nulidad del reglamento o plan y, en consecuencia, la de aspirar a la aniquilación de los efectos producidos. 


\section{Precisiones sobre el significado de los actos sancionadores y de los actos firmes}

El art. 73 LJCA impone distinguir entre los actos sancionadores y el resto de actos; y entre actos firmes y no firmes. Sólo los firmes quedan afectados por el art. $73 \mathrm{LJCA}^{72}$.

En ocasiones no es fácil saber cuándo se está ante un acto sancionador y cuando ante uno que, aun siendo de gravamen, no es sancionador. No procede que nos adentremos aquí en esa distinción. Sólo hay que insistir en que la diferenciación es capital sin que pueda extenderse lo previsto en el art. 73 LJCA para sanciones a otros actos de gravamen, aunque sean más perjudiciales que las propias sanciones ${ }^{73}$.

72 Los no firmes permanecen sin matices en la regla general derivada de los efectos retroactivos de la anulación del reglamento. Por ejemplo, para la STS de 17 de septiembre de 2009 (casación 4924/2005; Ar. 822 de 2010) la anulación de un plan comporta la anulación de sus actos de aplicación no firmes porque se impugnaron en tiempo. Si se anuló un plan y si separadamente se recurrió en tiempo un acto de aplicación, es claro que el art. 73 LJCA no se opone a la anulación de éste: "El acto administrativo al que se refiere este litigio (proyecto de compensación) se impugnó en su día directamente en plazo y forma legal. No adquirió firmeza, no alcanzándole por tanto la inmunidad regulada en este precepto". O se lee en la STS de 30 de enero de 2014 (casación 3045/2011; Ar. 802): “Cuando los actos dictados en aplicación de un reglamento ilegal no han alcanzado firmeza (...) entonces la anulación de la disposición general comunica sus efectos a los actos dictados en su aplicación...". Y para esos actos no firmes no importa que cuando la Administración los dictó aun no hubiese recaído la sentencia anulatoria del reglamento: la declaración de nulidad del reglamento deberá ser tomada en consideración aunque no pudo ser conocida por la Administración cuando produjo el acto impugnado. Lo deja claro, entre otras, la STS, Sección 2a , de 4 abril 2012 (Ar. 5177, casación 5301/2008). Una empresa mantenía que tenía derecho en los ejercicios 2002 y 2003 a unas deducciones fiscales en aplicación de un reglamento que fue anulado por STS de 2004. La STSJ dijo: "La clave exclusiva radica en que la norma ha sido expulsada en firme del ordenamiento jurídico, y aunque sus aplicaciones ya consolidadas queden al abrigo de la anulación conforme al artículo 73 LJCA, la eficacia general de la sentencia conlleva que el precepto declarado nulo no puede ser ya aplicado a partir de la publicación de la misma (...)". La empresa recurrió en casación y la STS reseñada lo desestima: "una liquidación puede ser anulada, como ha sucedido en el caso de autos, en función de un motivo que no existía en el momento de producirse aquella, sin que en absoluto sea cierto que un tribunal de justicia no pueda dejar de aplicar un precepto que la propia Administración, a la hora de regularizar la situación tributaria del contribuyente, haya aplicado, pues ese argumento conllevaría al absurdo de mantener la vigencia de un precepto declarado nulo por el Tribunal Supremo...".

73 Así, por ejemplo, lo que el art. 73 LJCA dice sobre las sanciones habrá de aplicarse a las multas y no a los actos que ordenen el restablecimiento de la realidad física aunque con frecuencia estos causan mayor daño que la multa. GONZÁLEZ PÉREZ, J. Comentarios a la Ley de la furisdicción Contencioso-Administrativa (Ley 29/1998, de 13 de julio), Civitas, 3 a ed., 1998, T. II, p. 1361, criticó que el precepto se limitara a los actos sancionadores por entender que hubiera sido preferible extender esa previsión a todos los de gravamen. Pero con claridad el legislador ha optado por restringirla a las sanciones, seguramente porque pensó que se trataba de una cuestión relacionada con la de la retroactividad in bonus de las normas sancionadoras. Ante ello, GARCÍA MANZANO, P. "Terminación del procedimiento", en J. LEGUINA VILLA y M. SÁNCHEZ MORÓN (Coords.), Comentarios a la Ley de la furisdicción Contencioso-Administrativa, Lex Nova, $2^{\mathrm{a}}$ ed., p. 348, apuntó la posibilidad de interpretar ampliamente el término sanción aquí empleado para incluir en él actos perjudiciales sin finalidad punitiva. Aunque esta solución parezca tentadora, no la consideramos 
Ningún acto administrativo es firme por su propia naturaleza; ninguno nace firme; sino que se convierte en firme, deviene firme o gana firmeza -expresiones todas ellas empleadas y sinónimas- por circunstancias posteriores a su producción. En concreto, por una de estas tres: porque no fue recurrido en plazo; porque fue objeto del pertinente recurso administrativo pero, desestimado ese recurso, no se interpuso en plazo recurso contra esa resolución del recurso; y porque el acto fue objeto de recurso contencioso-administrativo pero fue desestimado por sentencia irrecurrible desde el principio o por el transcurso del plazo para recurrirla. En síntesis, cabe decir que hay actos firmes por consentidos y actos firmes por confirmados.

Lo primero que es capital afirmar es que la declaración de nulidad del reglamento no reabre los plazos para impugnar los actos que lo aplicaron; no cabe volver a contarlos desde esa declaración de nulidad ${ }^{74}$. Es decir, que el acto que devino firme con anterioridad a la anulación del reglamento, firme se queda; y que el acto que todavía no había alcanzado firmeza cuando se anuló el reglamento que aplicó alcanzará su firmeza contando los plazos de recurso desde que se notificó tal acto sin que influya nada la fecha de la sentencia anulatoria del reglamento.

Lo segundo que hay que resolver para aplicar o no el art. 73 LJCA es si este precepto exige que la firmeza se haya ganado en algún momento determinado. No lo exige. Sólo dice que ha de tratarse de actos "administrativos firmes que lo hayan aplicado antes de que la anulación ganara efectos generales". Por tanto, el acto en cuestión ha de ser anterior a que la sentencia anulatoria del reglamento alcanzara efectos generales ${ }^{75}$. Pero no exige el art. 73 LJCA que el acto haya ganado firmeza antes de ese momento. En consecuencia, siendo el acto anterior a los efectos generales de la sentencia anulatoria del reglamento, es indiferente que también hubiese devenido firme antes de ese momento o que gane firmeza después. Y esto concuerda con lo que dijimos antes: si hubo un acto administrativo de aplicación del reglamento que cuando éste fue anulado con efectos generales podía todavía ser recurrido (o sea, que a la sazón no era firme) pero no se recurrió en lo que quedaba del plazo, devino firme y protegido por el art. 73 LJCA.

admisible y, en realidad, produciría distorsiones nada convenientes. Para todos los efectos -y, por tanto, también para lo previsto en este artículo 73- hay que acoger un concepto estricto de sanción.

74 PÉREZ ANDRÉS, A. A. (2000: 224-225), aunque como propuesta lege ferenda lo defiende como han hecho ESPEJO MEANA, M. R. (1992: 137) y GÓMEZ DÍAZ, A. B. (1997: 265 y 263). Pero ni así lo aceptan los tribunales ni sería una solución prudente ni conforme con una mínima seguridad jurídica. Vid. DOMÉNECH PASCUAL, G. (2002: 309). Es más, si se aceptara esa idea el art. 73 LJCA y su previsión para actos firmes perdería su sentido.

75 Para el caso del acto posterior a ese momento nada dice el art. 73 LJCA. También es posible que ese acto posterior a la sentencia anulatoria del reglamento quede firme. Pero eso, y la inatacabilidad que entraña, no tiene nada que ver con el art. 73 LJCA. Por eso, tal inatacabilidad la analizamos antes al abordar los efectos pro futuro de la anulación de reglamentos. 
La tercera observación deriva del hecho de que la firmeza de un acto depende de que fuese correctamente notificado a los sujetos legitimados para impugnarlo. Si no fue así, ni el acto, aunque antiguo, será firme ni, por ende, estará protegido por el art. $73 \mathrm{LJCA}^{76}$.

La cuarta observación deriva del hecho de que un acto alcanzará firmeza para uno u otro sujeto según la fecha en que a cada uno se le notificó y de la concreta acción que ejerza. Así que un acto puede ser firme para un sujeto y no para otro ${ }^{77}$.

A todo lo anterior todavía conviene añadir que el silencio administrativo negativo nunca es asimilable a un acto firme porque realmente ni siquiera es un acto administrativo y porque siempre cabe recurso contra él. Así que, si contra un acto de aplicación del reglamento anulado se interpuso recurso administrativo y no fue resuelto, aunque se haya producido el silencio negativo, no habrá acto firme de ningún género ni, consiguientemente, aplicación del art. 73 LJCA.

\section{Los actos no sancionadores firmes de aplicación del reglamento anulado}

De acuerdo con el art. 73 LJCA, estos actos (sean favorables o perjudiciales, sin perjuicio de lo previsto para los sancionadores) perviven aunque, tras la anulación del reglamento que aplicaron, hayan perdido fundamento y sean contrarios al orde-

76 Exponente de ello es la STSJ de Madrid 440/2014 de 1 abril (JUR \2014\1504): un sujeto pidió que se anulara una providencia de apremio como consecuencia de que la Ordenanza en que se basaba su deuda había sido judicialmente anulada; frente a ello, el Ayuntamiento alegó el art. 73 LJCA; y la Sala madrileña contestó que no era de aplicación el art. 73 LJ porque no había acto firme ya que no fue correctamente notificado: "no podemos entender como firmes y consentidas en este caso las liquidaciones de las que traen causa los apremios aquí impugnados porque no consta en autos que tales liquidaciones fueran notificadas... Así pues, cuando se dictó por el Tribunal Supremo (...) la sentencia firme que confirmó la declaración de nulidad (...) de la Ordenanza de autos, las liquidaciones no podían considerarse firmes y consentidas por no haber sido previamente notificadas y por ser susceptible, en este caso, de invocarse su nulidad de pleno derecho como causa de impugnación de sus apremios".

77 Ante la anulación de planes de urbanismo esto tiene gran virtualidad al existir la llamada acción pública que en muchos supuestos tiene un plazo de ejercicio superior al ordinario (actualmente art. 62.2 TRLS de 2015 según el cual, cuando esté motivada por la ejecución de obras ilegales, podrá ejercitarse hasta que transcurra el plazo en el que pueden adoptase medidas de protección de la legalidad urbanística). Lo aplica y explica con gran claridad la STSJ Andalucía/Málaga 2342/2016, de 30 de noviembre (JUR/2017/134867). Así las cosas, puede suceder que una licencia ilegal por haberse dictado de acuerdo con un plan luego anulado, aunque fuese notificada correctamente a todos los que debieron ser notificados y aunque para todos ellos alcanzó firmeza, sea todavía impugnable mucho después por el actor público que no fue notificado ni tuvo conocimiento de aquella licencia. No es una cuestión que, en lo que conozco, hayan abordado los tribunales ni es fácil resolverla. Pero parece necesario establecer algún límite porque, de lo contrario, teniendo en cuenta la amplitud de la acción pública y los periodos durante los cuales puede ejercerse, se arruinaría la utilidad del art. 73 LJCA y se perjudicaría la seguridad jurídica a la que el precepto sirve. 
namiento ${ }^{78}$. Perviven incólumes no porque sean actos sin vicios. Son sencillamente actos que, aunque con vicios (y, por tanto, ilegales), serán mantenido como si fuesen válidos $^{79}$. Por eso lo que se preserva, como dice acertadamente el art. 73 LJCA, es su "eficacia" (no afectará "a la eficacia", dice).

Y si se preserva su eficacia no es sólo que no se deba anular sino que se debe cumplir y que, si no se cumple, se deberá imponer su cumplimiento, en su caso, por ejecución forzosa. Así que, caso de incumplimiento por el particular al que ese acto imponga una conducta, la Administración podrá proceder por ejecución forzosa sin que quepa oponerle los vicios del acto ejecutado basados a su vez en la nulidad de la norma aplicada. Dicho de otra forma: ni cabrá atacar al acto declarativo ni a los actos de ejecución (providencia de apremio y subsiguientes, acuerdo de ejecución subsidiaria, multas coercitivas...) para llevar a la realidad aquél. Y si alternativamente el acto en cuestión comportaba deberes para la propia Administración el particular beneficiado podrá exigirle el cumplimiento (incluso por la vía del art. 29 LJCA) sin que la Administración pueda oponer una excepción de nulidad del acto: su pretensión deberá ser estimada sin que quepa invocar en contra la nulidad de la norma de origen.

Todavía hay más y muy importante: no se trata sólo de la validez de los actos para la pura ejecución de aquel acto firme sino también de todos aquellos encaminados a su eficacia en su sentido más amplio. Aquel acto salvado por el art. 73 LJCA debe ser tomado como referencia necesaria y eficaz para cualquier otra decisión que pretenda tomar la Administración. Esto es, que en todos sus actos posteriores la Administración debe partir de ese acto como si fuese válido y proceder en consecuencia. Lo contrario conduciría a la inutilidad absoluta de la preservación de actos firmes que consagra el art. 73 LJCA: tendríamos un acto que se salva de la aniquilación pero que no serviría para nada.

Así que esta pervivencia de la eficacia de los actos firmes dictados en ejecución de la norma anulada hace que incluso sean posibles nuevas actuaciones administrativas (típicamente, nuevos actos administrativos) que encuentran fundamento en aquellos y en el art. 73 LJCA, aunque ya no en la norma anulada. En cierto modo, pues, la norma anulada sigue ganando batallas después de muerta.

${ }_{78}$ Como hemos explicado antes, puede que haya actos que aplicaron el reglamento anulado y que, sin embargo, sean válidos porque encuentren fundamento en otra norma. Pero para reconocer esto es impertinente invocar el art. 73 LJCA. Así que sólo tiene sentido aplicar el art. 73 LJCA cuando el acto que se dictó en ejecución del reglamento anulado es de los que, tras la anulación del reglamento, es nulo o anulable.

79 CANO CAMPOS, T. (2004: 269 a 273), explica con acierto que la subsistencia de estos actos firmes "nada tiene que ver con su validez o adecuación a Derecho (...) El acto es inválido pero se mantiene...". 
Un ejemplo ilustrativo suministran las SSTS de 27 de noviembre de 2012 (casación 398/2012; Ar. 11021) y de 26 de septiembre de 2014 (casación 4042/2013; Ar. 5764). Se había anulado un plan de estudios universitarios en cuanto a la denominación "graduado o graduada en ingeniería de Edificación" y el tribunal de instancia decretó además la invalidez de cuantos títulos universitarios se hubieran expedido con esa denominación. Pero para el TS, tras afirmar que un plan de estudios es una norma reglamentaria, aplica el art. 73 LJCA y considera que no procede anular los títulos de graduado en Ingeniería de la Edificación ya expedidos y firmes. Esta jurisprudencia se aplica en materia tributaria de forma que anulado un reglamento en el que se basó la exigencia de cualquier tributo, subsisten los actos firmes de liquidación y no procede la devolución ${ }^{80}$.

Pero sobre todo el art. 73 LJCA ha encontrado terreno fértil ante la anulación de planes de urbanismo. Supuesto típico es el de las licencias de obras otorgadas al amparo del plan anulado que, si ganaron firmeza, son mantenidas ${ }^{81}$. Si esas licencias de obras firmes subsisten con plena eficacia, lo realizado a su amparo debe ser tratado como lícito, o sea, que el edifico construido debe ser considerado legal y, por tanto, susceptible

80 Por ejemplo, STS de 21 de marzo de 2000 (casación 4051/1994; Ar. 2821).

${ }^{81}$ Por no remontarnos más lejos, buena referencia ofrece la STS de 12 de febrero de 2008 (casación 5953/2005; Ar. 1885). Se anuló por sentencia un Estudio de Detalle. Pero antes se había otorgado licencia y se estaba construyendo un edificio. Quien en su momento recurrió contra el plan pidió que en ejecución de la sentencia anulatoria se declarase "la falta de vigencia de la licencia" y se suspendieran las obras. Pero para la sentencia reseñada, si la licencia se concedió antes de la sentencia anulatoria y ha devenido firme, la nulidad del plan no le afecta. Recuerda la jurisprudencia según la cual "la anulación de los instrumentos de planeamiento deja a salvo las licencias firmes". Y añade: "Del art. 73 LJCA se deduce inequívocamente que la sentencia que anuló el Estudio de Detalle (...) no conlleva por sí misma la anulación de los actos firmes derivados de él". En el caso dice que "la licencia es anterior a la (sentencia que anuló el plan), no consta que haya sido impugnada, será, en consecuencia, firme, y entra de lleno en la reserva del art. 73 LJCA". Muy similar es la STS de 19 de junio de 2009 (casación 5491/2007; Ar. 5785): también aquí una sentencia había anulado un Estudio de Detalle y, con esa base, se pedía en ejecución de la sentencia anulatoria del plan que se anulase la licencia otorgada y se demoliese el edificio; pero la sentencia, atendiendo a que aquella licencia ya era firme, rechaza la pretensión. Como la pretensión se ejercitaba en la ejecución de la sentencia anulatoria del plan, dice: “... de conformidad con una reiterada línea jurisprudencial (...) obvio es que la ejecución de la sentencia que nos ocupa no puede extenderse a la demolición del edificio (...) al encontrarse el mismo construido al amparo de una licencia de obras firme y no impugnada". Entre las más recientes citemos la STS 6/2017, de 16 de diciembre de 2016 (Ar. 137 de 2017): anulado un Plan Especial e indirectamente algunas determinaciones del planeamiento general, los recurrentes promovieron incidente de ejecución de sentencia pidiendo la demolición de 59 viviendas construidas en virtud de esos planes y subsidiariamente que el Ayuntamiento convirtiera otro suelo residencial en suelo de equipamiento para compensar el incremento de población. Tanto el TSJ como luego esta STS declararon no haber lugar a la ejecución en los términos solicitados pues ello iría más lejos de lo decidido en la sentencia y porque sería contrario a la jurisprudencia según la cual la anulación de planes no afecta a licencias firmes. Igualmente, entre otras muchas, SSTS 645/2017, de 6 de abril (casación 1497/2016; Ar. 1670), de 12 de marzo de 2015 (casación 1881/2014; Ar. 3626), de 19 de octubre de 2011 (casación 6157/; Ar. 1302 de 2012), de 4 de enero de 2008 (casación 27/2004). 
de usos lícitos. De modo que al decidir después sobre el otorgamiento de una licencia de ocupación o de obras de reforma habrá que partir necesariamente de la primera licencia como si fuese plenamente válida ${ }^{82}$. Esto mismo hay que extenderlo a los actos administrativos de legalización de construcciones dictados en aplicación del plan anulado ${ }^{83}$.

También el art. 73 LJCA puede preservar a los actos administrativos de gestión urbanística del plan anulado. Numerosas sentencias lo confirman respecto a proyectos de urbanización, proyectos de reparcelación o compensación, estatutos de juntas de compensación, cuotas giradas, etc.: todos ellos, aunque se produjeran en virtud de un plan anulado, si ganaron firmeza se mantienen a salvo. Así lo entendió ya hace años el TS para las cuotas ${ }^{84}$. Y esa jurisprudencia, ahora con el apoyo explícito del

${ }^{82}$ Lo desarrolla con acierto y cita de diversas sentencias PLAZA GONZÁLEZ, M. "La nulidad de los instrumentos de planeamiento general y la preservación de los actos firmes dictados a su amparo", Revista de Derecho Urbanístico y Medio Ambiente, no 312 (2017), pp. 119 a 122.

Lo que sí es posible -y más que probable- es que la construcción realizada al amparo de esa licencia sea disconforme con el Plan que ha revivido. Pero entonces lo lógico es considerar que queda en situación de fuera de ordenación; no de asimilado a fuera de ordenación, sino verdaderamente en situación de fuera de ordenación [vid. GONZÁLEZ SANFIEL, A. M. (2017: 448-449); y GIFREU FONT, J. (2017a: 185)]. Y, por tanto, debe dársele el régimen jurídico correspondiente a esa situación que en gran medida la LOUA remite a los planes. Ello permitirá (e incluso obligará), con las limitaciones en cada caso aplicables, otorgar nuevas licencias de ocupación, cambio de uso, obras de conservación... Pero ello no resta un ápice a lo aquí sostenido. Al contrario. Supone darle el mismo trato que a una licencia de obras perfectamente legal que después resulta disconforme con un nuevo plan.

83 A fin de cuentas esas legalizaciones (normalmente de edificios que nunca contaron con licencia) entrañan la concesión de una licencia ex post. Incluso se materializan y exteriorizan como un otorgamiento de licencia con la única singularidad de producirse a posteriori. Siendo así, no hay más remedio que dar a esas legalizaciones firmes el mismo trato que a las puras licencias firmes. Aquellas legalizaciones, por tanto, se benefician en igual medida del art. 73 LJCA. De modo que si, bajo la vigencia de un plan y por su conformidad con él, se legalizó una obra u otra actuación y si el acto que acordó esa legalización ha devenido firme permanecerá indemne ante la anulación del plan que aplicó. Para todos estos casos, consiguientemente, procede reiterar lo dicho sobre la situación de fuera de ordenación en que quedarán las correspondientes edificaciones y sobre la posibilidad de, con las limitaciones en cada caso aplicables a ese régimen, otorgar nuevas licencias de ocupación, cambio de uso, obras de conservación...

${ }^{84}$ Es oportuno recordar la STS de 26 de abril de 1996 (Ar. 5282) por producirse en recurso de casación en interés de la ley ( $\left.n^{\circ} 2737 / 1993\right)$. En el caso se trataba de la anulación de ciertas normas urbanísticas de Sevilla, anulación en cuya virtud se pidió y se concedió por la sentencia de instancia la devolución de lo pagado en virtud de una reparcelación. La sentencia recurrida negó que la firmeza del acto que impuso el pago fuese un freno porque las normas urbanísticas habían sido anuladas por razones sustanciales y no meramente formales "por lo que los actos firmes individuales dictados en aplicación de tales normas no están legitimados y su exigencia ya no tiene base alguna". El TS rechazó ese argumento. Dijo que "aunque en puridad de doctrina la declaración de nulidad de una disposición general, por ser de pleno derecho (...) produzca efectos ex tunc y no ex nunc, es decir, que los mismos no se producen a partir de la declaración, sino que se retrotraen al momento mismo en que se dictó la disposición declarada nula, esta eficacia, por razones de seguridad jurídica (...) se encuentra atemperada por el artículo 120 de la Ley de Procedimiento Administrativo, en el que con indudable aplicabilidad tanto en los supuestos de recurso 


\author{
art. 73 LJCA, se ha consolidado y extendido a otros actos de gestión ${ }^{85}$. Sin embargo \\ proceden dos matizaciones importantes.
}

administrativo como a los casos de recurso jurisdiccional, se dispone la subsistencia de los actos firmes dictados en aplicación de la disposición general declarada nula (...) en que los efectos son ex nunc y no ex tunc, si bien sólo respecto de los actos firmes, permaneciendo en cuanto a los no firmes la posibilidad de impugnarlos en función del ordenamiento jurídico aplicable una vez declarada nula la disposición general». Y así declaró "gravemente dañosa y errónea la doctrina y conclusión a que se llega en la sentencia objeto del presente recurso, y con estimación del mismo, debe establecerse como doctrina legal, que la estimación de un recurso interpuesto contra una disposición general -en el presente caso, determinadas Normas de un Plan General de Ordenación-, en cuanto implique la declaración de nulidad de aquélla y su derogación, sin distinción del motivo que sirvió de fundamento para tal declaración, no afectará a los actos firmes dictados en aplicación de la misma, los cuales permanecerán subsistentes”. Muy similar es la STS de 30 de octubre de 2000 (Ar. 9032) que resolvió una casación para la unificación de doctrina (nº 6473/1994). De nuevo se trataba de una petición de devolución de lo pagado como liquidación a cuenta de una reparcelación económica practicada en virtud de unos preceptos del PGOU de Madrid declarados nulos por sentencia y de nuevo el tribunal de instancia había estimado esa pretensión. Pero esta STS, en aplicación del art. 120 LPA/58, reitera "la subsistencia de los actos firmes dictados en aplicación de la disposición general declarada nula". Incluso aclara que ello también se produce ante una "liquidación provisional" porque era un acto impugnable y su falta de impugnación determinó su firmeza, con independencia de que después la liquidación definitiva también fuese impugnable por otras razones. En los mismos términos, entre otras, SSTS de 23 de diciembre de 1999 (casación 3805/1994; Ar. 9126) y de 31 de enero de 2000 (casación 2272/1994; Ar. 1929) que, con invocación del art. 120 LPA/58, rechazaron la devolución de lo pagado para la reparcelación por acto que quedó firme, petición que se había formulado ante la anulación del PGOU de Sevilla; y STS de 30 de septiembre de 2002 (casación 2611/1997; Ar. 8416) que, con el mismo fundamento del art. 120 LPA/58, desestimó la pretensión de devolución del "saldo provisional de la reparcelación económica" por haber sido establecido en acto que no se impugnó en tiempo, pese a que el PGOU de Madrid en que se basaba había sido anulado.

85 Entre las muestras más recientes citemos éstas:

- STS de 19 de junio de 2013 (casación 2713/2012; Ar. 5629): la anulación “de un Plan previo (...) no hace devenir la nulidad automática de los instrumentos aprobatorios de la gestión, pues, para acordarla, habrá de seguirse el trámite del artículo 109 de la Ley de la Jurisdicción Contencioso Administrativa con audiencia de las personas que puedan verse afectadas por la ejecución, singularmente las entidades urbanísticas...". Y “... puede operar el artículo 73 LJCA...”.

- STS de 12 de marzo de 2015 (casación 1881/2014; Ar. 3626). Se enfrenta con un caso en el que, en ejecución de la sentencia anulatoria de un plan, se pedía la anulación de diversos actos de aplicación; en concreto, entre otros, de un proyecto de reparcelación (que había sido confirmado por sentencia), de un proyecto de urbanización (que no se recurrió en tiempo) y de la liquidación de la cuota de urbanización (tampoco impugnada en su momento), así como la devolución de ésta. La sentencia, tras reproducir otras y distinguir entre los efectos de la nulidad de un plan sobre los planes que lo desarrollaron y sobre los actos administrativos que lo aplicaron, añade que "la eficacia expansiva de la nulidad ha de matizarse, en cambio, cuando se trata de actos de aplicación dictados en el desarrollo de una norma reglamentaria. En estos supuestos, en virtud del art. 73 LJCA, la declaración de nulidad de la norma reglamentaria comunica sus efectos a los actos dictados en su aplicación, a salvo, sin embargo, que dichos actos sean anteriores -esto es, se hayan dictado antes de que la anulación de la norma general produzca efectos generales- y hayan ganado firmeza -porque sus destinatarios no los recurrieron en tiempo y forma o porque, si lo hicieron, resultaron confirmados mediante sentencia firme". 
Primera: para las expropiaciones basadas en planes de urbanismo anulados los tribunales han consagrado otra solución por completo distinta en la que se niega la aplicación del art. $73 \mathrm{LJCA}^{86}$. Consideran que, anulado el plan en que se sustenta la declaración de utilidad pública y la necesidad de ocupación (art. 42.2 TRLS/2015), todo el procedimiento expropiatorio y todos sus actos deben ser declarados nulos sin que quepa invocar el art. 73 LJCA y sin que, por ende, queden a salvo los que devinieron firmes antes de la anulación del plan $^{87}$.

Segunda: hay algunas sentencias, aunque muy minoritarias, que dejan fuera del art. 73 LJCA a muchos de los actos de gestión urbanística. Unas veces se basan en una extravagante diferencia entre actos de aplicación y actos de ejecución ${ }^{88}$.

${ }_{86}$ Vid. GARCÍA GÓMEZ DE MERCADO, F. "Repercusión de la nulidad de planes y normas sobre los proyectos de expropiación”, en SORIA MARTÍNEZ, G. y BASSOLS COMA, M. (Coords.), Los efectos de la nulidad de los instrumentos de planeamiento urbanístico, Aranzadi, 2017, pp. 318 a 320; y GONZÁLEZ SANFIEL, A. M. (2017: 2017: 424-425).

${ }_{87}$ Exponente acabado de esta jurisprudencia es la STS de 23 de junio de 2009 (casación 4806/2005; Ar. 6766): "Tampoco puede compartirse la invocación del art. 73 LJCA cuya aplicación al caso, en cuanto a la no afectación de los actos del procedimiento expropiatorio firmes que se pretende por la parte, resulta contrario a la interpretación que efectúa la jurisprudencia de manera constante en los términos que antes se han expuesto. La anulación del planeamiento que justifica el procedimiento expropiatorio priva al mismo de la causa expropiandi...". Aunque sin ni siquiera citar el art. 73 LJCA, véanse en igual dirección las SSTS de 29 de junio de 2007 (casación 8543/2003, Ar. 3945), de 17 septiembre 2008 (casación núm. 450/2005, Ar. 4531), de 22 de junio de 2011 (casación 4271/2007, Ar. 5919), de 26 de enero de 2016 (casación 1142/2014, Ar. 362) y de 15 de septiembre de 2015 (casación 4271/2007). Critica esta jurisprudencia DE COMINGES CÁCERES, F. (2017: 58). Cuestión distinta es si la nulidad de la expropiación debe dar lugar a la restitución del bien expropiado o, manteniendo la transmisión de la propiedad, a una indemnización que compense no sólo la privación del bien sino también la nulidad, sobre todo cuando la devolución resulte imposible. Sobre ello, GARCÍA GÓMEZ DE MERCADO, F. (2017: 336 a 343).

${ }_{88}$ Así puede verse en la STS de 12 de noviembre de 2010 (Casación 6045/2009; Ar. 8294): anulado un Plan Parcial por sentencia, declara en ejecución de esa sentencia la nulidad de los Estatutos de la Junta de Compensación, la constitución de esa Junta, la aprobación del proyecto de urbanización y la del de reparcelación. Entre otros argumentos, apunta éste para excluir el freno del art. 73 LJCA ante este tipo de actos aunque fuesen firmes: "Interesa destacar que ha de tratarse de actos de aplicación $-<<$ que lo hayan aplicado $>>$ dice el art. 73- porque en el caso examinado los actos posteriores, que antes hemos citado, no son meros actos de aplicación de una disposición general, sino que añaden una cualidad superior, que son actos dictados en ejecución del propio plan parcial declarado nulo. Si esto es así, no resulta coherente considerar que no adolecen de vicio de invalidez alguna los actos dictados en ejecución de un plan parcial nulo, pues la única invalidez en que puede incurrir una disposición general (...) es la nulidad de pleno derecho. No estamos, en definitiva, ante un acto firme que carece del soporte normativo que le proporciona la disposición general, sino ante una norma reglamentaria, un instrumento de desarrollo urbanístico, que precisa, para consumarse sus previsiones y llevarse a la práctica sus determinaciones, de una serie de actos posteriores de ejecución". Aunque como dice PLAZA GONZÁLEZ, M. (2017: 117-118), ni esta sentencia establecía una doctrina con vocación de permanencia ni se ha consolidado, esta extraña distinción entre actos de aplicación y actos de ejecución, aparece también en alguna sentencia de Tribunales Superiores. Así, la STSJ de la Comunidad Valenciana 191/2017 de 23 marzo (JUR \2017\147893) dice: "No es aplicable el art. 73 LJCA (...) porque además no son actos de aplicación, sino que tanto estos como el Proyecto de Reparcelación y Urbanización, 
Otras se basan en considerar que ciertos actos de gestión urbanística son asimilables a normas ${ }^{89}$. Aunque lo hagan con argumentos teóricos oscuros y endebles, acaso busquen consecuencias prácticas más razonables porque forzoso es reconocer que la situación que se genera manteniendo los proyectos de urbanización y de reparcelación de un plan anulado es verdaderamente extraña y de consecuencias prácticas inciertas ${ }^{90}$.

aludidos por el apelante, son instrumentos de gestión y ejecución...". La verdad es que en este caso, como en el anterior, había otros argumentos para no aplicar el art. 73 LJCA (el proyecto de reparcelación y el de urbanización no eran firmes sino impugnados en su momento o incluso eran posteriores a la anulación del plan, etc.). Pero lo que nos importa es su propósito de dejar al margen del art. 73 LJCA a todos esos actos de gestión urbanística aunque se den todos los presupuestos en él establecidos.

89 Es el caso de la STS de 30 de enero de 2007 (casación 5303/2003) que declaró la nulidad de un proyecto de compensación por ser nulo el plan que ejecutaba y por el principio de jerarquía. Dice CALVO ROJAS, E. (2012: 831, nota 28), que es cuestionable esta sentencia dado que un proyecto de compensación carece de naturaleza normativa y, por ende, no cabe invocar la jerarquía entre normas. Tiene razón. Pero no deja de ser significativa esa citada STS que pone sobre la pista de las dificultades que generan los instrumentos de gestión aprobado para ejecutar un plan anulado.

90 En efecto, no se comprende cómo puede subsistir un instrumento aprobado para ejecutar un plan si éste está declarado nulo y debe ser ineficaz; tampoco se alcanza a saber cómo puede mantenerse la eficacia de una urbanización y reparcelación sino no hay ordenación de ese mismo suelo ni qué consecuencias prácticas tendrá; ni si puede haber una reparcelación sin un plan que justifique los aprovechamientos urbanísticos; ni si serán posibles o no licencias de obras; etc. Parece que hay una contradicción irreductible entre la anulación de un plan y la preservación de los instrumentos para convertirlo en una realidad física y jurídica; que hay que elegir entre una cosa y la otra, que acoger las dos al mismo tiempo es un imposible metafísico. Acaso podría decirse que esos instrumentos de gestión mantienen su validez pero que son ineficaces por falta de las condiciones para su eficacia. Pero debe notarse que lo que el art. 73 LJCA preserva es precisamente su eficacia. PLAZA GONZÁLEZ, M. (2017: 122), dice que la subsistencia de estos actos firmes en virtud del art. 73 LJCA no permite dictar nuevos actos administrativos "puesto que una cosa es que por razones de seguridad jurídica se mantengan tales actos firmes y otra distinta que ello permita, a su vez, producir nuevos actos administrativos sin la cobertura primaria que otorgaba el planeamiento finalmente anulado”. Y en p. 119 explica: “... el mantenimiento de actos urbanísticos firmes al amparo del (art. 73 LJCA) no produce el efecto práctico real esperado, ya que requieren de actos posteriores que (...) ya carecerán de tal cobertura. Por ejemplo, mantener (...) la validez y eficacia del acto de aprobación de un proyecto de urbanización puede ser poco práctico si a continuación no pueden obtenerse las licencias de obras (actos nuevos que, como tales carecerían ya de cobertura que otorga el citado artículo 73)". No es que "en ocasiones" pueda ser "poco práctico"; es más bien que nunca sería nada práctico, que siempre sería completamente inútil la aplicación del art. 73 LJCA y no serviría de ningún modo a la seguridad jurídica que es su fundamento y objetivo. Al contrario, sería un engorro porque habría actos que hay que considerar válidos y eficaces pero que no tienen ninguna virtualidad. Parece que estamos ante un callejón sin salida ¿O es que la salida consiste en decir que hay una imposibilidad legal de ejecutar la sentencia que anuló el plan? Lo cierto es que hay que optar ante una de estas dos soluciones: o no se aplica el art. 73 a los actos de gestión urbanística; o la anulación del plan que ya haya dado lugar a esos actos no tendrá consecuencias prácticas cuando tales actos hayan devenido firmes. 


\section{Los actos sancionadores firmes de aplicación del reglamento anulado ${ }^{91}$}

Si el art. 73 LJCA no contuviera una regla especial para las sanciones, éstas, cuando ya hubieran ganado firmeza, permanecerían intocables pese a haber perdido el fundamento que les daba el reglamento luego anulado. Esto, que sería tan contrario a la justicia y a los principios del Derecho Administrativo sancionador, es lo que ha querido excluir el último inciso del art. 73 LJCA. Si lo que hace el art. 73 para la generalidad de los actos administrativos es consagrar una excepción a la eficacia retroactiva de la anulación de reglamentos, lo que hace al final es excluir de esa excepción a los sancionadores. Excepción a la excepción que, en suma, devuelve las sanciones a la regla general, a la de la eficacia retroactiva de la declaración de nulidad de los reglamentos. Los actos sancionadores, pues, aunque sean firmes, sí que se verán afectados por la anulación del reglamento que aplicaron, sí que serán inválidos. Ahora bien, ello con dos condiciones cumulativas.

La primera, que esa anulación del reglamento beneficie al sancionado. No se aplicará si le perjudica, si comporta mayor sanción. Por eso dice el art. 73 LJCA que suponga "la exclusión o reducción de las sanciones"92.

${ }_{91}$ Nos referimos sólo a los actos sancionadores firmes pues, como ya explicamos antes (discutiendo la interpretación de Santamaría Pastor), si no son firmes (incluso aunque estuviesen completamente ejecutados), se verán afectados en su validez conforme a las reglas generales. Por tanto, recurridos en plazo, deberán ser anulados si realmente la anulación del reglamento los deja sin fundamento. En tal caso el art. 73 LJCA no es de aplicación ni cambia nada: basta invocar la eficacia ex tunc de la anulación de reglamentos para conseguir la nulidad de la sanción. Cosa distintas es que si la sanción está ya ejecutada (lo que es posible aunque no sea firme) haya que proceder a ciertas actuaciones para restablecer la situación legal: en ocasiones será muy simple (por ejemplo, habrá que devolver el importe de la multa cobrada); en otras será más difícil; y en alguna será incluso imposible (sanción de inhabilitación temporal ya cumplida). En este caso, quizá proceda una indemnización.

Y hablamos de sanciones impuestas en aplicación del reglamento anulado lo que comprende no sólo los casos en que sea el reglamento el que haya tipificado la infracción (lo que sería contrario al art. 25 CE y causa suficiente para su nulidad) sino también aquellos en los que el reglamento sólo aporta otras justificaciones de la sanción, como la antijuridicidad (por ejemplo, ante tipos infractores legales mediante normas sancionadoras en blanco que han de integrarse con un reglamento o plan que, por otras causas es luego anulado). En estos casos, como también explicamos en la misma nota, ni siquiera cabrá servirse de otra norma para dar nuevo fundamento a la sanción.

92 Esta condición se dará generalmente. Sólo cabe imaginar que no se dé cuando, tras la anulación de la sanción por la anulación del reglamento, la Administración se proponga sancionar en virtud del reglamento redivivo o en aplicación de otra norma y ello comporte mayor sanción. Pero eso, como ya explicamos antes, por el derecho a conocer la acusación y por el de defensa frente a esa nueva acusación, sólo podrá hacerse en un nuevo procedimiento sancionador. Ante la eventualidad de que ese segundo procedimiento sancionador se tramitase, cabría alegar que, aunque en virtud del nuevo fundamento procediese mayor sanción que la anulada, la nueva sanción tendría el límite máximo de la antes impuesta. Por ejemplo: un ayuntamiento, en aplicación de su ordenanza cívica, impone una sanción; la ordenanza es anulada por contradecir la Ley de Seguridad Ciudadana; en consecuencia, se anula la sanción impuesta; y, tras ello, el ayuntamiento se propone sancionar el mismo hecho ahora en aplicación de esa Ley de Seguridad Ciudada- 
La segunda, que la sanción no esté completamente ejecutada. Si es firme y está completamente ejecutada (sea por cumplimiento voluntario o por ejecución forzosa), la sanción se mantiene. Ya no importará que, con la anulación del reglamento, haya perdido su fundamento y sea ilegal. Para esta hipótesis, los actos sancionadores tienen el mismo régimen de cualquier acto devenido firme y permanecen tan campantes ante la anulación del reglamento o plan que aplicaron ${ }^{93}$.

Cuando se dan todas estas condiciones (sanción firme, anulación del reglamento en que se basó que beneficia al sancionado y sanción no completamente ejecutada) es cuando es aplicable el art. 73 in fine LJCA. Sólo en tal supuesto surge la excepción a la excepción, es decir, la vuelta a la regla general, a la de la eficacia ex tunc de la anulación de reglamentos, a la de la aniquilación de los efectos producidos por esos reglamentos ${ }^{94}$.

\section{Las sentencias firmes que hubiesen aplicado el reglamento anulado}

El art. 73 LJCA no sólo salva a los actos administrativos firmes sino también a las sentencias firmes. Aquí hay que entender por sentencia cualquier resolución judicial (también, por ejemplo, los autos de medidas cautelares o los dictados en ejecución de sentencias).

Frecuentemente se tratará de sentencias contencioso-administrativas que habrán confirmado (o eventualmente anulado) un acto administrativo dictado en aplicación del reglamento después anulado. En tal caso, la existencia de sentencia firme no añade nada al supuesto del acto firme porque en realidad se trata de un tipo de acto firme. Recuérdese que acto firme es tanto el que no fue recurrido en su momento como el que sí lo fue y ha sido confirmado por la sentencia que resolvió el recurso ${ }^{95}$.

na. Podrá hacerlo pero no creo que sea admisible que, aunque esa Ley comporte mayor sanción, se pueda imponer ésta. Esta segunda sanción tendrá el límite de la primeramente impuesta.

93 En esa dirección, SSTS de 3 de julio de 2007 (casación 345/2005; Ar. 6606), de 18 de julio de 2007 (casación 347/2005; Ar. 7447), de 13 de diciembre de 2007 (casación 346/2005; Ar. 743 de 2008), de 18 de diciembre de 2008 (casación 344/2005; Ar. 507 de 2008), de 21 de mayo de 2008 (casación 204/2006; Ar. 5405) y de 28 de mayo de 2008 (casación 203/2006; Ar. 5420).

94 Por tanto, la Administración no deberá intentar la ejecución de la sanción. Lo mejor es que siga la vía del art. 109.1 LPAC para revocar formalmente la sanción. Pero, aunque no lo haga, si intenta la ejecución forzosa, contra los actos de ejecución cabrán recursos que deberán prosperar. Cuando la sanción consista en multa, al sancionado le bastará con no pagarla; y puede recordarle a la Administración la declaración de nulidad del reglamento. En cualquier caso, si la Administración inicia la vía de apremio, cabrá impugnar la providencia y otros actos de ejecución: la resolución sancionadora será firme, pero no lo serán estos actos de ejecución que cabrá recurrir exitosamente con apoyo en el art. 73 in fine LJCA.

95 Así, la STS 1984/2016, de 26 de julio (Ar. 3806; casación 3499/2015) se enfrentó con el caso de una licencia firme concedida para la construcción de un hospital en virtud de la modificación de un PGOU después anulada. Y aplica la doctrina que ya hemos expuesto sobre la permanencia de las licencias 
Si acaso cabe añadir que si el acto es firme no por su falta de impugnación sino por haber sido confirmado por sentencia firme, se potencia su normal intangibilidad por el refuerzo que le presta la cosa juzgada ${ }^{96}$. Salvando esta eventual diferencia el caso de la sentencia firme que en aplicación del reglamento anulado confirmó un acto de ejecución de ese reglamento no es más que un supuesto específico dentro del ámbito más amplio de los actos firmes ${ }^{97}$.

Ahora bien, puede haber casos de sentencias firmes que aplicaron el reglamento luego anulado y que no enjuiciaron un acto administrativo. Pueden ser contencioso-administrativas (por ejemplo, las que resolvieron recursos contra reglamentos de desarrollo del reglamento luego anulado o contra una actuación material amparada por ese mismo reglamento). O pueden ser sentencias de otro orden jurisdiccional. En todos estos casos, la referencia explícita del art. 73 LJCA a las sentencias firmes adquiere relevancia propia y obliga a mantener su eficacia aunque hayan perdido su fundamento al ser anulado el reglamento que aplicaron. Se salvan no ya por la

firmes aunque en el caso lo era, no por no haber sido recurrida, sino por haber sido recurrida y confirmada por sentencia firme. El caso es que, pedida la anulación de la licencia en ejecución de la sentencia que declaró la nulidad del plan, la denegó con invocación del art. 73 LJCA. Y sugerente es la STS de 19 de octubre de 2011 (casación 6157/2008; Ar. 1302 de 2012) que concluye que "debe desestimarse el presente recurso (...) toda vez que las peticiones (... deducidas ante la Sala de instancia en el incidente de ejecución del que dimana el recurso) o bien estaban referidas a sentencias firmes que se habían pronunciado sobre actos administrativos de aplicación del Decreto anulado, o bien a actos administrativos firmes dictados en aplicación de la citada disposición". Es pues indiferente a estos efectos que se esté ante actos firmes por no haber sido recurridos o de sentencias firmes que confirmaron actos administrativos.

96 Por eso la STS de 12 de marzo de 2015 (casación 1881/2014; Ar. 3626), que aborda la pretensión de nulidad de varios actos de ejecución (proyecto de reparcelación, de urbanización, cuotas...) de un Plan Parcial previamente anulado, aunque rechaza todas las pretensiones anulatorias por tratarse de actos firmes, se muestra especialmente enérgico respecto del proyecto de reparcelación: había sido confirmado por sentencia firme y esto constituye "un límite infranqueable". Pero, en realidad, la misma suerte corrieron las pretensiones anulatorias frente a otros actos (proyecto de urbanización y cuotas) que simplemente eran firmes por no haber sido recurridos en tiempo. La misma solución se observa en el caso de sanciones. Lo prueba la ya aludida STS de 18 de diciembre de 2007 (recurso 344/2005): no sólo se trataba de una sanción completamente ejecutada y firme sino que su firmeza derivaba de que, aunque impugnada en plazo, fue confirmada por sentencia. Y ante ello esta STS de 2007 confirma su negativa a la revisión de oficio porque "existe cosa juzgada". Pero conste que a igual conclusión se habría llegado (y se llegó en sentencias que abordaron sanciones impuestas en virtud del mismo reglamento nulo) aunque la sanción fuese firme simplemente por el hecho de que no se recurrió en su momento; simplemente no se habría contado con el refuerzo adicional de la cosa juzgada. Podría, no obstante, observarse alguna diferencia si se aceptara el acto consentido que se aprobó en ejecución del reglamento anulado puede ser objeto de revisión de oficio mientras que no podría serlo si se tratara de un acto confirmado por sentencia firme.

${ }_{97}$ No sólo es que pueda haber actos firmes de aplicación del reglamento anulado sin sentencia confirmatoria. Es que, además, puede haber actos que fueron confirmados por una sentencia que desestimara un recurso fundado en otras razones. Si luego se alega otro fundamento (la nulidad del reglamento aplicado) no habría cosa juzgada (pues nada se juzgó sobre tal causa de invalidez) pero sí que jugaría el límite del art. 73 LJCA. 
fuerza de la cosa juzgada sino por este art. $73 \mathrm{LJCA}^{98}$. Seguramente, sin embargo, habrá que excluir las sentencias penales con las mismas condiciones que las expuestas para las sanciones administrativas ${ }^{99}$. Pero, exceptuado ese supuesto, las demás sentencias firmes quedan salvadas por el art. 73 LJCA. Piénsese en el reglamento en cuya virtud se dictó sentencia civil que condenara a un sujeto privado a pagar a otro una cantidad. O piénsese sobre todo en la sentencia contencioso-administrativa que desestimó el recurso contra el reglamento aprobado por orden ministerial en desarrollo del aprobado por Decreto siendo éste luego anulado; o en la que confirmó un plan parcial de desarrollo de un plan general después anulado. Esto altera en parte lo que antes se dijo sobre el "efecto cascada" y el resultado final conjunto puede resultar poco o nada armonioso pues no lo será, por ejemplo, que se anule un plan general, que se consideren igualmente nulos todos sus planes de desarrollo, pero que quede en pié uno porque fue recurrido sin éxito.

\section{Efectos "por sí mismas" de las sentencias anulatorias de reglamentos y efectos por vías complementarias ¿Cabe la revisión de oficio?}

Hemos prescindido hasta ahora de que el art. 73 LJCA lo que realmente dice es que las sentencias anulatorias de disposiciones administrativas generales no afectarán "por sí mismas". Es momento de abordar ya esa expresión, algo enigmática, que puede significar cosas muy distintas ${ }^{100}$.

98 La diferencia es relevante: la cosa juzgada tiene límites subjetivos y objetivos; el art. 73 LJCA no.

99 No tendría sentido otra cosa: no estaría justificado dar mejor trato al sancionado que al penado; no hay razón para entender que las sanciones de que habla el art. 73 LJCA son sólo las administrativas y no las penales; y no tendría sentido que a este respecto las sentencias que anulan reglamentos tengan régimen distinto que las sentencias que anulan leyes (arg. art. 40.1 LOTG). Y en todo caso cabría interponer contra aquella sentencia penal firme que aplicó el reglamento después anulado el recurso de revisión del art. 954.1.e) LECrim. Volveremos después sobre esto último.

100 Incluso sin salirse de su literalidad, cabría sostener que lo que el art. 73 LJCA significa es que la anulación de un reglamento no afectará siempre y necesariamente a la eficacia de los actos y sentencias firmes que lo aplicaron y que sólo en ciertos casos sí que podría afectar a su eficacia; que todo dependerá de que el acto encuentre una cobertura jurídica distinta de la que le daba el reglamento anulado; que si no la tiene será nulo o anulable; y que en tal caso así habrá que declararlo. Esa interpretación podría vislumbrarse al menos en la STS de 2 de marzo de 2016 (casación 1626/2015; Ar. 940) cuando dice que el art. 73 LJCA "no impone a fortiori y en todo caso la inmunidad de cualesquiera actos firmes, pues la locución por si mismas puede ser conjugada con la posibilidad de invalidación sobrevenida de tales actos. Excluirla de plano supondría hacer de mejor condición los actos administrativos firmes que los propios reglamentos derivados de uno superior anulado". Parece querer decir que la anulación de un reglamento sí que puede llevar a la anulación de los actos firmes que lo aplicaron igual que se admite que lleva a la anulación de los reglamentos que lo desarrollaron. Este planteamiento causa vértigo porque pone al borde del abismo a todos los actos firmes dictados en ejecución de un reglamento anulado. Además sorprende su argumento porque siempre se ha aceptado que las consecuencias de la nulidad de un reglamento son diametralmente 
Es seguro que esa expresión significa como mínimo que ni la sentencia que anule el reglamento contendrá también anulación de los actos firmes que lo aplicaron ni tal anulación podrá pronunciarse en ejecución de aquella sentencia. Así lo acepta el $\mathrm{TS}^{101}$. Menos incluso cabrá que ni en esa sentencia ni en su ejecución se anulen sentencias firmes que aplicaron el reglamento anulado.

Sentado lo anterior, la duda que suscita la expresión "por sí mismas" del art. 73 LJCA es si las sentencias anulatorias de reglamentos pueden afectar a los actos y sentencias firmes que aplicaron ese reglamento de otra forma, no "por sí mismas", no automáticamente, pero sí por alguna vía complementaria.

Empecemos por las sentencias firmes que hayan aplicado el reglamento anulado. No se da ninguno de los vicios de nulidad del art. 238 LOPJ. Tampoco ninguna de los motivos de revisión de sentencias contencioso-administrativas del art. 102

distintas para los reglamentos de desarrollo y para los actos de ejecución. Pero esta afirmación de la sentencia (en otros pasajes, dicho sea de paso, impecable), además de no aparecer en ninguna otra sentencia, no se concreta ni desarrolla en ésta. Sólo si concretara algo más esa idea valdría la pena adentrarse en los terrenos ignotos a los que parece conducir. Pero con esa sola afirmación cabe pensar que sólo hay un cierto exceso verbal y que realmente no pretende poner patas arriba las explicaciones tradicionales dentro de las cuales se acota -y acotamos nosotros- el posible significado del art. 73 LJCA. Así que, aunque literalmente posible, descartamos esa interpretación.

101 Nos bastan para probarlo algunas de las sentencia que ya citamos antes para demostrar que las sentencias anulatorias de un plan no afectan a las licencias firmes otorgadas a su amparo porque en realidad abordaban esa cuestión, no en un recurso autónomo, sino precisamente en ejecución de las sentencias que anularon el plan; y lo que concretamente declararon es que no es posible anular esas licencias firmes en el trámite de ejecución de esas sentencias. Así, SSTS de 4 de enero de 2008 (casación 27/2004); de 12 de febrero de 2008 (casación 5953/2005; Ar. 1885); de 19 de junio de 2009 (casación 5491/2007; Ar. 5785); de 12 de marzo de 2015 (casación 1881/2014; Ar. 3626); 1984/2016, de 26 de julio (casación 3499/2015; Ar. 3806); y 6/2017, de 16 de diciembre (Ar. 137 de 2017). Y lo mismo que de las licencias hay que decir en principio de otros actos de aplicación del plan anulado, como los proyectos de reparcelación o de urbanización. Pese a todo, no siempre el TS se pronuncia en estos términos. Ya explicamos antes que respecto a actos de gestión (proyectos de reparcelación, estatutos y bases de juntas de compensación...) el TS se muestra vacilante e introduce matices confusos que le llevan a decir a veces que la nulidad del plan en que se apoyan acarrea su invalidez, incluso aunque sean firmes. Y ahora hay que añadir que en ocasiones ha dicho que ello puede ser objeto de la ejecución de la sentencia anulatoria del plan. Es el caso de la STS de 19 de junio de 2013 (casación 2713/2012; Ar. 5629): ante una sentencia que anuló una Modificación de unas Normas Subsidiarias entendió que en ejecución de ella, aunque no se podía anular las licencias concedidas, sí que se podía anular un plan de desarrollo y, además, que es lo que ahora nos importa, las Bases, Estatutos y constitución de la Junta de Compensación, así como los Proyectos de Compensación y de Urbanización. Y ello sin parar mientes en si eran o no ya firmes. Bien es verdad que ello lo remitió a la tramitación del incidente del art. 109 LJCA con audiencia de todas las personas afectadas, por lo que, al cabo, no se sabía que es lo que se podría resolver en ese incidente y si al menos allí habría que salvar esos actos si fuesen firmes. Pero afortunadamente el asunto volvió al TS (justamente tras tramitar el tribunal de instancia ese incidente) y entonces, en su sentencia 1285/2016, de 2 de junio (casación 3716/2015; Ar. 3123) todo quedó claro: con fundamento en el art. 73 LJCA y como quiera que esos actos de gestión habían quedado firmes declaró que no procedía anular tales actos en ejecución de la sentencia anulatoria del plan. 
LJCA. Ni los de revisión de sentencias civiles (art. 510 LEC). Sí sería posible, por el contrario, recurso de revisión contra la sentencia penal firme que hubiese condenado en aplicación del reglamento luego anulado. Lo permite ahora el art. 954.1.e) LECrim "cuando, resuelta una cuestión prejudicial por un tribunal penal, se dicte con posterioridad sentencia firme por el tribunal no penal competente para la resolución de la cuestión que resulte contradictoria con la sentencia penal". Pues lo que habrá hecho el juez penal al aplicar el reglamento -ya sea planteándose y aceptando su legalidad, ya sea sin ni siquiera plantearse su ilegalidad- habrá sido entrar en una cuestión prejudicial administrativa. Salvo en este caso muy excepcional, no habrá vía para combatir las sentencias firmes que aplicaron el reglamento. Así que con esa sola excepción, el art. 73 LJCA significa que no hay cauce para que la sentencia anulatoria de un reglamento afecte de ningún modo a las sentencias firmes que lo aplicaron: ni "por sí misma" ni de ninguna otra forma.

Veamos ahora la situación respecto a los actos administrativos firmes. En concreto, como se trata de actos firmes contra los que no caben los recursos ordinarios y como no se da ninguno de los supuestos del recurso administrativo extraordinario de revisión (art. 125 LPAC), lo que cabe cuestionar es si es posible la revisión de oficio de los actos administrativos de aplicación del reglamento anulado. Lo que sobre todo se ha planteado es si el particular interesado tiene la acción de nulidad del art. 106.1 LPAC. Pero la cuestión debe plantearse en términos más amplios: lo que importa saber es si las distintas vías que bajo ese nombre regulan los arts. 106 a 111 LPAC, tanto las abiertas a los particulares interesados como las exclusivas de la Administración autora del acto, se pueden utilizar contra esos actos firmes que aplicaron el reglamento anulado y precisamente invocando como causa de su invalidez la sentencia anulatoria del reglamento.

Algunos autores se han mostrado favorables a esa posibilidad, al menos a la del art. 106.1 LPAC a solicitud del interesado ${ }^{102}$.

En la jurisprudencia no encontramos una respuesta terminante. Entre las SSTS favorables a la revisión la que más claramente afirma esa posibilidad sigue siendo la

102 AGOUÉS MENDIZÁBAL, C. (2017: 387 y 401); BELADÍEZ ROJO, M. (1994: 324); DE ASIS ROIG, A. E. "La conservación de actos no firmes dictados en ejecución de una disposición general declarada nula", REDA, nº 59 (1988), pp. 455 y ss.; FERNÁNDEZ SALMERÓN, M. (2002: 396 a 399); GONZÁLEZ PÉREZ, J. Los recursos administrativos y económico-administrativos, 1975, pp. 724 y ss.; PÉREZ ANDRÉS, A. A. (2000: 229 a 231); ROSENDE VILLAR, C. (2002: 155); SANTAMARÍA PASTOR, J. A., antes en La nulidad de pleno derecho de los actos administrativos, Instituto de Estudios Administrativos, 1972 y ahora en 2010: 733-734. Concretamente sobre esta posibilidad ante anulación de planes de urbanismo, TRAYTER JIMÉNEZ, J. M. (1996: 400) y GIFREU FONT, J. (2017a: 176). 
de 23 de septiembre de $2003^{103}$. Explicaba esta STS que "la doctrina jurisprudencial no ha sido inequívoca". Y en el fondo confesaba, más bien, que la postura mayoritaria era la contraria a la que ella acogió y que "la tesis expuesta se aparta en cierta medida del planteamiento más tradicional de la cuestión que mantenía a ultranza la eficacia de los actos firmes dictados al amparo de una disposición de carácter general declarada nula". Pero lo que nos interesa es saber si esta jurisprudencia innovadora de la STS de 23 de septiembre de 2003 ha tenido continuidad. Lo cierto es que no hay muchas sentencias recientes sobre lo que ahora nos incumbe. Y sólo obiter dicta encontramos alguna que apunta en la misma dirección ${ }^{104}$.

Salvo error, los pronunciamientos más interesantes son los que ya hace más de diez años, resolvieron sobre las solicitudes de revisión de oficio de una serie de empresas sancionadas en aplicación del Reglamento de la Denominación de Origen Rioja

103 Casación 380/1999 (Ar. 7789). Ésta es la situación que afrontó: unas empresas tuvieron que pagar unas cantidades y entregar una parcela para obtener licencia; ello porque así lo establecieron unos actos dictados de conformidad con un plan general; ese plan general fue anulado pero aquellos actos habían devenido firmes; las empresas pidieron la revisión de oficio de aquellos actos y la Administración la denegó; recurrieron y el TSJ desestimó su recurso. El TS revocó la sentencia, declaró nulos los actos que habían impuesto el pago y condenó al Ayuntamiento a devolver todo lo entregado. Entendió que, "por razones de seguridad jurídica", el art. 73 LJCA establezca que "la declaración de nulidad radical de una disposición de carácter general no acarrea automáticamente la desaparición de dichos actos". Ahora bien, que no la acarree automáticamente (que no la acarree "por sí misma") no significa que no la pueda acarrear indirectamente; en concreto, no significa que no la pueda acarrear tras la revisión de oficio prevista para los actos incursos en vicio de nulidad de pleno derecho por haber perdido todo fundamento al ser anulado el reglamento que aplicaron. Y dice: "Para declarar la nulidad radical de los actos administrativos dictados al amparo de una disposición general nula de pleno derecho es inexcusable la vía de la revisión de oficio de dichos actos, siendo la decisión administrativa susceptible de control jurisdiccional (artículos 102.1 de la Ley 30/1992...)". Completó su idea tratándola de conciliar con el art. 102.4 Ley 30/1992 (idéntico al actual art. 106.4 LPAG) mediante una interpretación gramáticas sutil y digna de mejor causa: el "vigente artículo 102.4 de la Ley 30/1992, utiliza la expresión $<<$ sin perjuicio $>>$, seguida del modo subjuntivo $<<$ subsistan $>>$, que en nuestra lengua expresa una posibilidad, es decir que pueden subsistir o no, mientras que, si el legislador hubiese pretendido la subsistencia en todo caso de los actos, habría utilizado expresiones como la de subsistiendo los actos firmes dictados a su amparo, las de subsistirán o subsisten, evidenciadoras de una realidad y no de una mera posibilidad". Por otro lado, añadió que esta revisión de oficio, como todas, tiene los límites que antes plasmaba el art. 106 de la Ley 30/1992 y ahora el art. 110 LPAC: "Aun cuando el acto firme, privado de la norma a cuyo amparo se dictó, careciese de cobertura en el ordenamiento jurídico, no procede declararlo nulo de pleno derecho cuando por la prescripción de acciones, por el tiempo transcurrido o por otras circunstancias, tal declaración resulte contraria a la equidad, a la buena fe, al derecho de los particulares o a las leyes".

104 Por ejemplo, STS de 12 de febrero de 2008 (casación 5953/2005; Ar. 1885): aunque en aplicación del art. 73 LJCA salvó de la nulidad una licencia firme dictada de conformidad con un plan anulado, añadió que ello era "sin perjuicio de la decisión que pueda adoptarse en un procedimiento de revisión de oficio y de las consecuencias indemnizatorias derivables de aquélla, conforme a lo establecido en el art. 102 Ley 30/1992 ... dado que la conformidad o no a derecho de la licencia urbanística quedó imprejuzgada en sede jurisdiccional". También aceptó en alguna ocasión esta revisión de oficio el Consejo de Estado. Por ejemplo, en su dictamen de 30 de noviembre de 1995 (Repertorio de Doctrina Legal 67). 
ante el hecho de que, cuando las resoluciones sancionadoras habían ganado firmeza y habían sido cumplidas en su totalidad, se anuló judicialmente ese Reglamento. En todos los casos la Administración inadmitió la solicitud de revisión de oficio y en todos los casos ello fue confirmado por el $\mathrm{TS}^{105}$ : consideró que no cabía revisar de oficio sanciones impuestas en aplicación de un reglamento anulado judicialmente; esto es, que la sentencia que anuló el reglamento, no ya es que no comportase por sí misma la invalidez de los actos firmes que lo habían aplicado, sino que tampoco abría la posibilidad de su revisión de oficio. Y si esto lo excluyó para sanciones, que son los actos rodeados de más garantías y en los que la desaparición de su base normativa puede afectar más directamente a derechos fundamentales (art. $25 \mathrm{CE}$ ), con mayor razón hay que excluirlo para cualquier otro género de acto ${ }^{106}$.

Ante estas vacilaciones jurisprudenciales conviene ensayar una respuesta. Además, debe tenerse en cuenta que parte de la jurisprudencia citada se elaboró antes de la LJCA cuyo art. 73 no dice lo mismo que los preceptos precedentes. Según creemos, hay factores que inclinan claramente por negar la posibilidad de revisión de oficio.

- Primero. Se dice siempre, y con razón, que el art. 73 LJCA tiene por justificación y fin la seguridad jurídica. Pero si se admitiera la revisión de oficio ese fin quedaría por completo arruinado. Es más, el art. 73 LJCA resultaría perturbador porque se perjudicaría menos la seguridad jurídica admitiendo que la anulación se declare en ejecución de la sentencia que dejando eso a procedimientos posteriores y a los ulteriores contencioso-administrativos en que se impugnase la resolución de la revisión de oficio. Es decir, que si se admite la revisión de oficio en estos casos la finalidad del art. 73 LJCA que es proteger la seguridad jurídica quedaría completamente maltrecha y ese art. 73 acentuaría más bien el peligro de inseguridad.

- Segundo. Habría que limitar la revisión de oficio a los actos firmes por consentidos. Pero quedarían excluidos los actos firmes por confirmados; esto es, aquellos que sí que fueron objeto de recurso contencioso-administrativo que no prosperó.

105 Lo hizo en sus sentencias de 3 de julio de 2007 (casación 345/2005; Ar. 6606), de 18 de julio de 2007 (casación 347/2005; Ar. 7447), de 13 de diciembre de 2007 (casación 346/2005; Ar. 743 de 2008), de 18 de diciembre de 2008 (casación 344/2005; Ar. 507 de 2008), de 21 de mayo de 2008 (casación 204/2006; Ar. 5405) y de 28 de mayo de 2008 (casación 203/2006; Ar. 5420).

106 Sin embargo, no puede dejar de observarse que en los casos objeto de esas sentencias se presentaban elementos complementarios que fueron tenidos en cuenta por el TS de modo que no es tan fácil sacar una conclusión definitiva para lo que nos ocupa. Así, esas sentencias se refieren a veces al hecho de las mismas sanciones habían sido confirmandas por sentencias firmes (y al correspondiente límite a la revisión de la cosa juzgada) y a que tenían otros fundamentos normativos además de reglamento anulado. Ante ello cabe dudar si la respuesta habría sido la misma sin esos otros condicionantes; es decir, si se habría mantenido pura y simplemente que el art. 73 LJCA impide revisar de oficio los actos firmes que aplicaron el reglamento anulado. 
Porque en tal caso, según se suele mantener, la revisión de oficio queda excluida ${ }^{107}$. Así, pues, como máximo, el "por sí mismas" del art. 73 LJCA significaría para parte de los actos firmes (los confirmados por sentencia) que no hay ninguna posibilidad de afectar a su eficacia y que para otros (los consentidos) sí, lo que cual arroja un resultado conjunto poco armonioso.

Tercero. Si, como antes hemos visto, respecto a las sentencias firmes no hay, salvo en algunos casos de las penales, ningún medio similar al de la revisión de oficio ni recursos extraordinarios que permitan impugnarlas por haber aplicado un reglamento luego anulado ${ }^{108}$, aceptar que los actos administrativos firmes por consentidos que aplicaron el reglamento anulado pueden ser objeto de revisión de oficio produciría en realidad una asimetría en los resultados finales de ese precepto (unas serían sus consecuencias para sentencias y para actos confirmados por sentencia y otras pare el resto de actos firmes) que no parecen racionales ni queridos por el art. 73 LJCA.

Por todo esto y por las últimas SSTS que hemos visto entendemos que cabe sostener que las sentencias anulatorias de reglamentos o planes no comportan la anulación de los actos firmes dictados en su aplicación ni "por sí mismas" ni de ninguna otra forma; que no conducen ni directa ni indirectamente a su invalidez porque no cabe contra ellos la revisión de oficio en ninguna de sus variantes ${ }^{109}$. Es esto, además,

107 Expresamente lo establecen los arts. 213.3 LGT y 14.1.b) TRLHL. Fuera del ámbito tributario, se llega a la misma conclusión invocando que la revisión sería contraria a la cosa juzgada. Acabada muestra de ello es la STS de 25 de noviembre de 2015 (casación 269/2014; Ar. 5411). Pero es cuestionable que haya cosa juzgada por varias razones. Sobre todo por estas: porque se estará invocando una causa de nulidad distinta de la que fue desestimada en la sentencia; porque hay un nuevo hecho relevante que precisamente consiste en la sentencia anulatoria del reglamento; porque habría dos sentencias con cosa juzgada, la que confirmó el acto y la que anula el reglamento que aplicó el acto. Además, en todo caso, la cosa juzgada de las sentencias desestimatorias sólo afecta a las partes, no a terceros, por lo que si fuesen estos los que instan la revisión de oficio, no podría oponérseles la cosa juzgada. Sobre la posibilidad o no de revisión de los actos confirmados por sentencia vid. BUENO ARMIJO, A. "La revisión de oficio", en H. GOSÁLBEZ PEQUEÑO (Dir.), La nueva Ley del Procedimiento Administrativo Común, Wolters Kluwer, 2016, p. 449; SUAY RINCÓN, J. "La caracterización jurídica de la potestad de revisión de oficio", en SORIANO GARCÍA, J. E. (Dir.), Por el Derecho y la libertad. Libro homenaje al Profesor Fuan Alfonso Santamaría Pastor, Iustel, 2014, II, p. 1385; y REBOLLO PUIG, M. (1998: 525). Pero incluso al margen de la invocación de la cosa juzgada, otras SSTS, como la de 13 de febrero de 2015 (casación 537/2013; Ar. 1052) niegan también la posibilidad de revisión de oficio con otro argumento: que el art. 102.1 Ley 30/1992, como ahora el art. 106.1 LPAC, se refieren a actos "que no hayan sido recurridos en plazo". Con todo, en algún supuesto excepcional se ha admitido la revisión de oficio de actos confirmados en sentencia (así en la STS 57/2017, de 18 de enero, que reiteradamente insiste en que se basa en las características singulares del caso; casación 1469/2015; Ar. $1198)$.

108 CARLÓN RUIZ, M. (2005: 364 y su nota 96).

109 Así lo mantiene también el magistrado DE COMINGES CÁCERES, F. (2017: 57): el art. 73 LJCA "constituye un límite a la revocación de los actos de gestión urbanística y licencias firmes concedidas durante la vigencia del plan anulado, tanto por la vía de la revisión de oficio como por la del recurso extraordinario de revisión". Y cita SSTS de Galicia en este sentido. Matizada e interesante es la postura 
lo que concuerda mejor con la idea explicada antes de que el acto firme que subsiste es eficaz como si fuese válido.

Si acaso quepa matizar esta respuesta tan drástica que no se compadece del todo con el tenor literal de los arts. 73 LJCA y 106 a 111 LPAG ni arroja siempre resultados razonables. En esa línea habría que distinguir entre actos favorables y desfavorables y admitir más fácilmente que estos últimos sí que puedan ser revocados conforme al art. 109.1 LPAC $^{110}$. Y quizá proceda aceptar que la propia Administración pueda, por iniciativa propia, combatir los actos favorables firmes que aplicaron el reglamento o plan posteriormente anulado; en concreto, por el cauce del art. 106 LPAC si se trata de actos nulos o por el del art. 107 LPAC si son anulables y realmente lesivos del interés general. Esto puede ocurrir porque habrá supuestos en que esos actos firmes sean un estorbo para la regulación (sobre todo para la ordenación urbanística vigente, la que haya revivido o la que la sustituya). Ello sin perjuicio de que, como se cuida de señalar el art. 106.4 LPAC, pueda darse origen a indemnizaciones.

Incluso aunque se admitiera que los particulares sí que pueden instar la revisión de oficio de estos actos firmes, ello estaría limitado a los casos de actos consentidos (no confirmados por sentencia) nulos de pleno derecho, nunca a los anulables porque el art. 107 LPAC sólo lo puede seguir la Administración motu proprio. Este límite es muy relevante porque, como ya explicamos, lo normal será la anulabilidad de los actos dictados en aplicación del reglamento anulado, no su nulidad de pleno derecho que hay que considerar excepcional.

Además, en cualquier caso, para que la revisión prospere habrá que superar los límites del art. 110 LPAC y, dado que se tratará de actos en aplicación de un reglamento que creó una apariencia de legalidad, con mucha frecuencia la revisión será contraria a la buena fe y a la equidad.

En definitiva, incluso aceptando a efectos dialécticos la revisión de oficio de los actos firmes que aplicaron el reglamento (o plan) anulado a instancia de los particulares, sería una posibilidad con muy reducido alcance práctico.

GONZÁLEZ SANFIEL, A. M. (2017: 425 a 429): aunque no niega radicalmente la posibilidad de revisión de oficio en estos casos, aclara que ello "no significa que sea algo sencillo ni siquiera conveniente, al menos de manera generalizada"; por el contrario, afirma que "no es una solución adecuada" sino "una temeridad". Y sobre todo destaca que los límites que impone el art. 110 LPAC se alzarán en estos supuestos para impedir la revisión de oficio.

110 Vid. PÉREZ ANDRÉS, A. A. (2000: 220-221 y 231). 


\section{BIBLIOGRAFÍA}

AGOUÉS MENDIZÁBAL, C., "La modulación de los efectos de la invalidez de los reglamentos", en LÓPEZ RAMÓN, F. y VILLAR ROJAS, F. (Coords.), El alcance de la invalidez de la actuación administrativa, AEPDA/INAP, 2017.

ASIS ROIG, A. E. de, "La conservación de actos no firmes dictados en ejecución de una disposición general declarada nula", Revista Española de Derecho Administrativo, $\mathrm{n}^{\circ} 59$ (1988).

BAÑO LEÓN, J. M., Derecho Urbanístico común, Iustel, 2009.

BASSOLS COMA, M., "La asimilación de los planes de urbanismo a normas reglamentarias y problemática jurídica de su anulación judicial", en SORIA MARTÍNEZ, G. y BASSOLS COMA, M. (Coords.), Los efectos de la nulidad de los instrumentos de planeamiento urbanístico, Aranzadi, 2017.

BELADÍEZ ROJO, M., Validez y eficacia de los actos administrativos, Marcial Pons, 1994.

BUENO ARMIJO, A., "La revisión de oficio", en GOSÁLBEZ PEQUEÑO, H. (Dir.), La nueva Ley del Procedimiento Administrativo Común, Wolters Kluwer, 2016.

CALVO ROJAS, E., "Los planes urbanísticos como disposiciones de carácter general. Problemas que suscita la declaración de nulidad de los instrumentos de planeamiento. Suspensión cautelar de la efectividad de los planes impugnados en vía jurisdiccional", Administración y justicia. Un análisis jurisprudencial. Liber amicorum Tomás-Ramón Fernández, Civitas, 2012.

CANO CAMPOS, T., La invalidez sobrevenida de los actos administrativos, Civitas, 2004.

GARLÓN RUIZ, M., La cuestión de ilegalidad en el contencioso-administrativo contra reglamentos, Civitas, $2^{a}$ ed., 2005.

COMINGES CÁCERES, F. de, "Los efectos de la anulación judicial de un plan general. La necesaria modulación de la equiparación de planes y disposiciones reglamentarias. Propuestas de mejora del sistema", Revista de Derecho Urbanístico y Medio Ambiente, $\mathrm{n}^{\circ} 314$ (2017).

DÍAZ GONZÁLEZ, G. M., "Las limitaciones jurisprudenciales del recurso indirecto contra reglamentos", Revista Vasca de Administración Pública, no 99-100 (2014).

DOMÉNECH PASGUAL, G., La invalidez de los reglamentos, Tirant lo Blanch, 2002.

ESPEJO CAMPOS, A., "Dominio público y BIC como límites a la nulidad en el ámbito urbanístico", en LÓPEZ RAMÓN, F. y VILLAR ROJAS, F. El alcance de la invalidez de la actuación administrativa, AEPDA/INAP, 2017. 
ESPEJO MEANA, M. R., "Nulidad de reglamentos: efectos jurídico-materiales de la sentencia sobre los actos dictados en su aplicación. Comentario a la STS de 21 de julio de 1991 (Ar. 5594)", Revista Andaluza de Administración Pública, no 12 (1992).

FERNÁNDEZ SALMERÓN, M., El control jurisdiccional de los reglamentos. Procedimiento administrativo, proceso judicial y potestad reglamentaria, Atelier, 2002.

GARCÍA GÓMEZ DE MERCADO, F., "Repercusión de la nulidad de planes y normas sobre los proyectos de expropiación", en SORIA MARTÍNEZ, G. y BASSOLS COMA, M. (Coords.), Los efectos de la nulidad de los instrumentos de planeamiento urbanístico, Aranzadi, 2017.

GARCÍA LUENGO, J., "La declaración de nulidad en vía administrativa de disposiciones generales", Revista de Administración Pública, n 154 (2001).

GARCÍA MANZANO, P., "Terminación del procedimiento", en LEGUINA VILLA, J. y SÁNCHEZ MORÓN, M. (Coords.), Comentarios a la Ley de la furisdicción Contencioso-Administrativa, Lex Nova, $2^{\text {a }}$ ed., 1995.

GIFREU FONT, J., "Los efectos jurídicos de la anulación del planeamiento urbanístico sobre los actos singulares de aplicación. Especial referencia a los instrumentos de ejecución y títulos administrativos habilitantes dictados a su amparo", en SORIA MARTÍNEZ, G. y BASSOLS GOMA, M. (Coords.), Los efectos de la nulidad de los instrumentos de planeamiento urbanístico, Aranzadi, 2017.

- "La discordancia de los títulos y fincas inscritas en el Registro de la Propiedad con la realidad urbanística derivada de la nulidad de los planes", en SORIA MARTÍNEZ, G. y BASSOLS COMA, M. (Coords.), Los efectos de la nulidad de los instrumentos de planeamiento urbanístico, Aranzadi, 2017.

GÓMEZ DÍAZ, A. B., "La eficacia de las sentencias contencioso-administrativas: entre la dogmática y la ingeniería judicial", Revista de Administración Pública, ${ }^{\circ}$ 144 (1997).

GÓMEZ-FERRER MORANT, R., "Nulidad de reglamentos y actos dictados durante su vigencia”, Revista Española de Derecho Administrativo, no 14 (1977).

GÓMEZ-FERRER RINCÓN, R., La imposibilidad de ejecución de sentencias en el proceso contencioso-administrativo, Civitas, 2008.

GONZÁLEZ PÉREZ, J., Los recursos administrativos y económico-administrativos, Cívitas, 1975.

- "Una exclusión del recurso contenciosos-administrativo por vía jurisprudencial: el control de vicios de procedimiento de elaboración de disposiciones generales", Revista Española de Derecho Administrativo, no 9 (1976). 
- Comentarios a la Ley de la furisdicción Contencioso-Administrativa (Ley 29/1998, de 13 de julio), Civitas, $3^{\text {a }}$ ed., 1998.

GONZÁLEZ SANFIEL, A. M., "Invalidez sobrevenida de los actos de aplicación del planeamiento urbanístico nulo", en SANTANA RODÍGUEZ, J.J. (Coord.), Estudios sobre el planeamiento territorial y urbanistico, Tirant lo Blanch, 2011.

- "El principio de especialidad como límite a la declaración de nulidad del planeamiento", en BASSOLS COMA, M., MENÉNDEZ REXACH, A. y GIUFREU, J. (Coords.), El derecho de la ciudad y el territorio. Libro homenaje a Manuel Ballbé Prunes, INAP, 2016.

- "Límites a la declaración de nulidad de los planes", en F. LÓPEZ RAMÓN y VILLAR ROJAS, F. (Coords.), El alcance de la invalidez de la actuación administrativa, AEPDA/INAP, 2017.

HUERGO LORA, A., Las pretensiones de condena en el contencioso-administrativo, Aranzadi, 2000.

- "Los efectos en otros procesos de las sentencias no firmes que declaran la nulidad de un reglamento", en GARCÍA DE ENTERRÍA, E., y ALONSO GARCÍA, R. (Coords.), Administración y justicia. Un análisis jurisprudencial. Liber amicorum Tomás-Ramón Fernández, Civitas, 2012.

IGLESIAS GONZÁLEZ, F., "Responsabilidad patrimonial por nulidad del planeamiento", en SORIA MARTÍNEZ, G., y BASSOLS COMA, M. (Coords.), Los efectos de la nulidad de los instrumentos de planeamiento urbanístico, Aranzadi, 2017.

JORDANO FRAGA, J., "Efectos de la invalidez de los reglamentos en el ámbito tributario: el caso del canon de los puertos deportivos de Andalucía", en LÓPEZ RAMÓN, F. y VILLAR ROJAS, F. (Coords.), El alcance de la invalidez de la actuación administrativa, AEPDA/INAP, 2017.

LAVILLA ALSINA, L., "La revisión de oficio de los actos administrativos", Revista de Administración Pública, n⿳ 34 (1961).

LÓPEZ RAMÓN, F., "La calificación de los vicios de los reglamentos", Revista de Administración Pública, n⿳ 205 (2018).

MUÑOZ MACHADO, S. y GARRO MARINA, M., "La eficacia de las sentencias no firmes (impugnación de una corriente jurisprudencial: desde la sentencia de 17 de septiembre de 2008 a la de 10 de octubre de 2011)", en GARCÍ́A DE ENTERRÍA, E., y ALONSO GARCÍA, R. (Coords.), Administración y justicia. Un análisis jurisprudencial. Liber amicorum Tomás-Ramón Fernández, Civitas, 2012. 
PAREJO ALFONSO, L. y ROGER FERnÁNDEZ, G., Comentarios al Texto Refundido de la Ley de Suelo (Real Decreto Legislativo 2/2008, de 20 de junio), Iustel, 2009.

PÉREZ ANDRÉS, A. A., Los efectos de las sentencias de la Jurisdicción Contencioso-Administrativa, Aranzadi, 2010.

PLAZA GONZÁLEZ, M., "La nulidad de los instrumentos de planeamiento general y la preservación de los actos firmes dictados a su amparo", Revista de Derecho Urbanístico y Medio Ambiente, no 312 (2017).

REBOLlO PUIG, M., "Comentarios a los artículos 72 y 73 LJCA”, Revista Española de Derecho Administrativo, no 100 (1999).

ROSENDE VILLAR, C., La eficacia frente a terceros de las sentencias contencioso-administrativas, Aranzadi, 2002.

SANTAMARIA PASTOR, J. A., La Ley Reguladora de la Furisdicción Contencioso-Administrativa. Comentario, Iustel, 2010.

- "Una imprevista disfunción del sistema urbanístico: la mortalidad judicial de los planes", Práctica Urbanística, no 141 (2016).

SAZ CORDERO, S. del, “¿Debemos repensar los poderes del juez ante la constatación de la ilegalidad de una disposición general o acto administrativo? La anulación parcial del Plan General de Madrid de 1997: un inmejorable ejemplo", Revista Vasca de Administración Pública, no 99-100.

SORIA MARTÍNEZ, G., "Los efectos de la nulidad de los planes en la clasificación y el régimen jurídico del suelo y la ordenación urbanística”, en G. SORIA MARTÍNEZ y M. BASSOLS COMA (Coords.), Los efectos de la nulidad de los instrumentos de planeamiento urbanístico, Aranzadi, 2017.

SORIA MARTÍNEZ, G., y GARBAYO BLANCH, J., "Consecuencias de la nulidad del plan sobre los contratos civiles de transmisión”, en G. SORIA MARTÍNEZ y M. BASSOLS COMA (Coords.), Los efectos de la nulidad de los instrumentos de planeamiento urbanístico, Aranzadi, 2017.

SUAY RINCÓN, J., "La caracterización jurídica de la potestad de revisión de oficio", en SORIANO GARCíA, J. E. (Dir.), Por el Derecho y la libertad. Libro homenaje al Profesor Fuan Alfonso Santamaría Pastor, Iustel, 2014.

TARDÍO PATO, J. A., "Los efectos ex tunc de la anulabilidad, Revista Española de Derecho Administrativo, no 184 (2017). 
- "El mito de los efectos ex nunc de la anulación por anulabilidad", en LÓPEZ RAMÓN, F. y VILLAR ROJAS, F. (Coords.), El alcance de la invalidez de la actuación administrativa, AEPDA/INAP, 2017, pp. 195 a 205.

TRAYTER JIMÉNEZ, J. M., El control del planeamiento urbanístico, Civitas, 1996. 